Hydrol. Earth Syst. Sci. Discuss., https://doi.org/10.5194/hess-2018-507

Manuscript under review for journal Hydrol. Earth Syst. Sci.

Discussion started: 30 October 2018

\title{
Submarine groundwater discharge site in the First Salpausselkä ice- marginal formation, south Finland
}

\author{
Joonas J. Virtasalo ${ }^{1}$, Jan F. Schröder ${ }^{2}$, Samrit Luoma ${ }^{3}$, Juha Majaniemi ${ }^{3}$, Juha Mursu ${ }^{4}$, Jan Scholten ${ }^{2}$ \\ ${ }^{1}$ Marine Geology, Geological Survey of Finland (GTK), Espoo, FI-02150, Finland \\ 5 Institut für Geowissenschaften, Christian-Albrechts-Universität Kiel, Kiel, D-24118, Germany \\ ${ }^{3}$ Groundwater, Geological Survey of Finland (GTK), Espoo, FI-02150, Finland \\ ${ }^{4}$ Applied Geophysics, Geological Survey of Finland (GTK), Kuopio, FI-70211, Finland
}

Correspondence to: Joonas J. Virtasalo (joonas.virtasalo@gtk.fi)

\section{Abstract}

Submarine groundwater discharge (SGD) has been implicated as a significant source of nutrients and other potentially harmful substances to coastal sea. Although the number of reported SGD sites has increased recently, their stratigraphical architecture and aquifer geometry are rarely investigated in detail. This study analyses a multifaceted dataset of offshore seismic sub-bottom profiles, multibeam and sidescan sonar images of the seafloor, radon measurements of seawater and 15 groundwater, and onshore ground-penetrating radar and refraction seismic profiles in order to reconstruct the detailed stratigraphical architecture of a high-latitude SGD site, which is connected to the Late-Pleistocene First Salpausselkä icemarginal formation on the Hanko Peninsula in Finland. The studied location is characterized by a sandy beach, a sandy shore platform that extends 100-250 m seaward sloping gently to ca. $4 \mathrm{~m}$ water depth, and a steep slope to ca. $17 \mathrm{~m}$ water depth within ca. $50 \mathrm{~m}$ distance. The onshore radar and offshore seismic profiles are correlated based on unconformities, following the allostratigraphical approach. The aquifer is hosted in the distal sand-dominated part of an ice-contact subaqueous fan foreset. It is interpreted that gravel and coarse sand interbeds and lenses in the distal foreset, and, potentially, coarse couplet layers in the overlying glaciolacustrine rhythmite, provide conduits for localized groundwater flow. The SGD takes place predominantly through pockmarks on the seafloor, which are documented on the shore platform slope by multibeam and sidescan sonar images. Elevated radon-222 activity concentrations measured $1 \mathrm{~m}$ above seafloor confirm SGD from two pockmarks with fine sand surface sediment, whereas there was no discharge from a third pockmark that was covered with a thin organic-rich mud layer. The thorough understanding of the local stratigraphy and the geometry and composition of the aquifer that have been acquired in this study are crucial for successful hydrogeological modeling and flux studies at the SGD site. 
Hydrol. Earth Syst. Sci. Discuss., https://doi.org/10.5194/hess-2018-507

Manuscript under review for journal Hydrol. Earth Syst. Sci.

Discussion started: 30 October 2018

\section{Introduction}

Submarine groundwater discharge (SGD) is understood as the flow of groundwater, or quite often a mixture of groundwater and seawater, from the seabed to the coastal sea (Burnett et al., 2003; Moore, 2010). Although the volume of groundwater SGD is generally small compared to rivers, groundwater flow from the seafloor often carries high concentrations of

5 nutrients, trace metals and other land-derived contaminants (e.g. Moore, 2010; Szymczycha et al., 2012, 2016). Therefore, SGD associated fluxes potentially have considerable effects on the marine ecosystems.

Eutrophication is a major concern for large parts of the Baltic Sea (Andersen et al., 2017). The main cause of this poor ecological status is the excess supply of nutrients by rivers and the atmosphere. Although the main nutrient supply routes to

10 the Baltic Sea are well known, detailed studies of SGD and associated fluxes have been carried out only at a couple of locations along the south coast: the Eckernförde Bay in Germany (e.g. Whiticar and Werner, 1981; Schlüter et al., 2004) and the Puck Bay in Poland (e.g. Jankowska et al., 1994; Szymczycha et al., 2012, 2016). In addition, seafloor morphological features such as terraces and pockmarks, interpreted to be produced by SGD, have been documented from the Stockholm Archipelago (Söderberg and Flodén, 1997; Jakobsson et al., 2016) and SGD rates have been modelled through a ${ }^{224}$ Ra mass

15 balance offshore Forsmark in Sweden (Krall et al., 2017). For the Puck Bay, Szymczycha et al. (2012) calculated that SGD contributes ca. $3 \%$ of the local annual influx of dissolved inorganic nitrogen and as much as $30 \%$ of the annual influx of phosphate. Although further studies are required, SGD associated fluxes can be expected to significantly impact the ecological status of the Baltic Sea.

20 The key subseafloor aquifers in the Eckernförde Bay and Forsmark are Late Pleistocene glaciofluvial sand deposits (Jensen et al., 2002; Krall et al., 2017). In the Stockholm Archipelago, silty couplet layers in glacial varved clays act as groundwater conduits (Söderberg and Flodén, 1997). Although comparable glacial sediments are well-known from Finland, no SGD sites have been documented previously from the Finnish waters.

25 Coastal aquifers are vulnerable to seawater intrusion, either as a result of sea level rise or storm surges, both of which are predicted to increase due to climate change (Wong et al., 2014; Pellikka et al., 2018). Groundwater abstraction for the needs of coastal cities further increases the vulnerability of low-lying aquifers to high sea levels (Ferguson and Gleeson, 2012). Recent groundwater modeling and hydrogeochemical studies show that the water quality of a glaciogenic coastal aquifer in the Hanko Peninsula, south Finland, may be compromised due to groundwater pumping and the predicted sea-level rise and increase in precipitation (Luoma and Okkonen, 2014; Luoma et al., 2015).

Over the last years, measurements of radon $\left({ }^{222} \mathrm{Rn}\right)$ in seawater have been widely employed to trace and quantify SGD from shallow coastal aquifers (e.g., Schlüter et al., 2004; Burnett et al., 2003, 2008; Peterson et al., 2008; Gleeson et al., 2013; 
Hydrol. Earth Syst. Sci. Discuss., https://doi.org/10.5194/hess-2018-507

Manuscript under review for journal Hydrol. Earth Syst. Sci.

Discussion started: 30 October 2018

Tait et al., 2013; Schubert et al., 2014; Sadat-Noori et al., 2015). Radon is a natural radioactive noble gas that is highly enriched in groundwater by two to four orders of magnitude compared to seawater (Prakash et al., 2018) due to the decay of

${ }^{226} \mathrm{Ra}$ in aquifer sediments (Andrews and Wood, 1987; Mullinger et al., 2009).

5 The aim of this study is to reconstruct the detailed stratigraphical architecture and aquifer geometry of a SGD site in the Late-Pleistocene First Salpausselkä ice-marginal formation on the Hanko Peninsula in Finland. Whereas the majority of known SGD sites are situated in low and mid-latitudes, this study provides a rare case from high latitudes. This is also the first study of a SGD site to combine offshore and onshore sub-surface profiling surveys in order to obtain a full picture of the local stratigraphy and aquifer geometry cross the shoreline. The offshore seismic profiles and the onshore ground-penetrating

10 radar (GPR) and refraction seismic profiles are collected by fundamentally different techniques, but can be correlated on the basis of unconformities recognized in the profiles, following the allostratigraphical approach. Multibeam and sidescan sonar images document pockmarks on the seafloor, which are interpreted to be produced by SGD. Finally, radon measurements demonstrate groundwater discharge from two of the three measured pockmarks.

\section{Study area}

15 The coastal aquifer studied here belongs to the First Salpausselkä ice-marginal formation, which runs as a wide ridge on the Hanko Peninsula, located on the southern coast of Finland (Fig. 1). The Late Pleistocene deposits rest on the Paleoproterozoic crystalline bedrock that mainly consists of quartz diorite and granodiorite (Kielosto et al., 1996). The First Salpausselkä was deposited during the Younger Dryas climatic event, in the course of deglaciation of the Fennoscandian continental ice sheet. According to varve chronology and paleomagnetic dating, the deposition of the First Salpausselkä began at 12300 varve years ago (Saarnisto and Saarinen, 2001). Varve counting by Sauramo (1923) indicates that the First Salpausselkä was deposited over 217 years, and the ice margin retreated from the area ca. 12100 varve years ago. Cosmogenic ${ }^{10} \mathrm{Be}$ age of $12500 \pm 700$ for the ice margin retreat supports the varve chronology (Rinterknecht et al., 2004). The First Salpausselkä was deposited as a narrow ridge of contiguous glaciofluvial fans and local feeding eskers that were formed along the ice-margin grounding line (Virkkala, 1963; Glückert, 1986; Fyfe, 1990; Kujansuu et al., 1993), in an icecontact lake that was more than $100 \mathrm{~m}$ deep in Hanko (Fyfe, 1990). After the ice margin retreat, the till and glaciofluvial gravel and sand deposits were successively covered by glaciolacustrine rhythmically alternating (varved) silt and clay, and postglacial lacustrine poorly-bedded clay (Virtasalo et al., 2007, 2014). At ca. 7600 years ago, the deposition of postglacial lacustrine clay came to an end with erosion and the emplacement of a thin transgressive silt-sand sheet as a result of the midHolocene marine flooding and establishment of brackish-water conditions in the Baltic Sea Basin (Virtasalo et al., 2007,

30 2016). The deposition soon resumed with the organic-rich brackish-water mud drift that is strongly influenced by waves and near-bottom currents, and still continues today. 
Hydrol. Earth Syst. Sci. Discuss., https://doi.org/10.5194/hess-2018-507

Manuscript under review for journal Hydrol. Earth Syst. Sci.

Discussion started: 30 October 2018

As a result of the initially rapid glacio-isostatic land uplift (today $4 \mathrm{~mm}$ /year; Kakkuri, 2012), the highest peaks of the First Salpausselkä in Hanko began to emerge from the sea by 5000 years ago (Eronen et al., 2001). The top of the ice-marginal formation was exposed to waves and eventually to wind as it gradually rose from the sea. The original ridge morphology became truncated and flattened from the top, the glaciolacustrine and postglacial lake silts and clays were removed, and the underlying glaciofluvial deposits were reworked by wind waves and currents (Virkkala, 1963; Glückert, 1986; Fyfe, 1990; Kujansuu et al., 1993). Fine sand was redeposited as beach ridges on the south side of the peninsula and partially reworked into aeolian dunes (Fyfe, 1990).

The Hanko area belongs to the temperate coniferous-mixed forest climate zone with cold, wet winters. The mean annual air

10 temperature is $6{ }^{\circ} \mathrm{C}$, with the mean minimum temperature of $-4.2{ }^{\circ} \mathrm{C}$ and the mean maximum temperature of $16.6^{\circ} \mathrm{C}$. The mean annual precipitation is $670 \mathrm{~mm}$ during the period 1981-2010 (Finnish Meteorological Institute, 2017). The annual mean sea surface salinity ranges between 4.5 and 6.5 PSU and temperature between 4 and $9{ }^{\circ} \mathrm{C}$ during the period $1927-2011$ (Merkouriadi and Leppäranta, 2014). The low salinity results from the high riverine runoff from the large Baltic Sea catchment area, and from the long distance to the narrow connection to the World Ocean through the Danish straits. The sea

15 is annually covered by ice on average 69 days (1891-2012), and the ice season usually ends in April (Merkouriadi and Leppäranta, 2014). The sea is essentially non-tidal, but irregular water level fluctuations of as much as $\pm 2.5 \mathrm{~m}$ take place as a result of variations in wind and atmospheric pressure.

\section{Materials and methods}

Seafloor seismoacoustic surveys were carried out in May 2017. The surveys were run at 5 knots, using a suite of multibeam

20 and sidescan sonar and seismic survey equipment onboard r/v Geomari of the Geological Survey of Finland: $200 \mathrm{kHz}$ Atlas Fansweep 20 multibeam sonar, 100 and $500 \mathrm{kHz}$ Klein 3000 sidescan sonar, Meridata $28 \mathrm{kHz}$ pinger sub-bottom reflection profiler, Massa TR-61 A 3.5-8 kHz compressed high-intensity radar pulse (CHIRP) reflection profiler, and ELMA 250-1300 $\mathrm{Hz}$ seismic reflection profiler. The parallel survey lines were spaced at $75 \mathrm{~m}$ intervals to permit full multibeam coverage, and orientated N-S on the basis of typical wind (wave) direction. Shore-normal seismic survey lines were collected in order to 25 permit correlation with onshore profiles. Sound velocity profiles of the water column were measured using a Reson SVP 15T profiler. Multibeam data were collected and processed with Hypack, and visualized with Fledermaus 7.4.4b software. A relative backscatter mosaic was produced using a GeoCoder algorithm. Sub-bottom profiler and sidescan sonar data were collected and interpreted using Meridata MDCS and MDPS software. The seismic units and corresponding sediment types were interpreted following Virtasalo et al. (2007, 2014). Sound velocities used for converting the seismic two-way travel 30 time to sediment unit thickness were as follows: brackish-water mud, $1480 \mathrm{~m} / \mathrm{s}$; postglacial lake and glaciolacustrine clay, $1550 \mathrm{~m} / \mathrm{s}$; glaciofluvial sediments, $1600 \mathrm{~m} / \mathrm{s}$; till, $1850 \mathrm{~m} / \mathrm{s}$ (Sviridov, 1977; Virtasalo et al., 2014). 
Hydrol. Earth Syst. Sci. Discuss., https://doi.org/10.5194/hess-2018-507

Manuscript under review for journal Hydrol. Earth Syst. Sci.

Discussion started: 30 October 2018

Hydrology and

Earth System

(c) Author(s) 2018. CC BY 4.0 License.

Sciences

Discussions

(c) (i)

Onshore ground-penetrating radar (GPR) profiles were recorded in October 2017, along survey lines that were oriented as to continue the offshore seismic survey lines, and along perpendicular survey lines that followed the arc-shaped shoreline and the shore parallel road 500-800 m inland. The GPR profiles were collected using a GSSI SIR 4000 Control Unit with a GSSI antenna operating at $200 \mathrm{MHz}$ central frequency. Data were recorded using a $220 \mathrm{~ns}$ time window. Location was recorded

5 using a Trimble GeoXH 6000 handheld GPS receiver with VRS network correction. Location, topography, and GPR profiles were combined and processed using Geodoctor 3.2 software. Signal processing methods applied were background removal, low pass and high pass filtering and linear gain. Relative permittivity value of six was used, which corresponds to sandy dry soil (Annan, 2009). The GPR profiles were interpreted following Neal (2004). The interpretation was aided by eight unpublished groundwater drill logs from the survey area, obtained from the POVET database (Finnish Environment Agency,

10 2018) and GTK databases.

Refraction seismic survey was run in April 2018 along the shoreline. The survey consisted of nine linear spreads of 24 geophones. The geophones were positioned at $5 \mathrm{~m}$ intervals, except in the middle and both ends of the spreads the geophones were positioned at $2.5 \mathrm{~m}$ intervals. The total length of each spread was $100 \mathrm{~m}$. The beach sand surface was frozen at the time

15 of surveys, so that the geophones were installed in drilled holes. The position of each geophone was recorded by GPS. Small explosive charge (80-120 g dynamite), drilled to 50-70 cm below ground was used as a source of seismic wave. Five source points (shot points) were used for each spread (at the both ends, in the middle, and $100 \mathrm{~m}$ away from the both ends, outside of the geophone spread). Seismic refraction data was recorded by a digital 24 channel Geometrics StrataVisor NZXP seismograph, using a sampling interval of $0.125 \mathrm{~ms}$ and a record length of $0.3 \mathrm{~s}$. The seismograph was triggered by a signal

20 from the blasting device. The first arrival times of $\mathrm{P}$ waves were extracted from seismograms using Rimrock Geophysics Sipik software. Elevation data for geophone and shot point locations was obtained from LiDAR data. The P wave first arrival data was interpreted using ray tracing technique in Geometrics SeisImager software.

Radon-222 measurements of seawater and groundwater were carried out in May 2018. First, a survey of seawater surface

${ }^{222} \mathrm{Rn}$ activity concentrations was carried out onboard the research boat Gridi of the Geological Survey of Finland. The survey was run at 1.4 knots along the edge of the shore platform, as well as along a couple of shore-normal transects. Two pumps that continuously supplied water for the ${ }^{222} \mathrm{Rn}$ measurements were fixed at ca. $50 \mathrm{~cm}$ water depth in the same frame with a Sea \& Sun Technology CTD90M multiprobe that was recording pressure (depth), temperature, conductivity (salinity), dissolved oxygen, turbidity, and flow velocity and direction values at 1 minute intervals. Seawater ${ }^{222} \mathrm{Rn}$ measurements were

30 carried out using two identical systems in parallel, each equipped with a 3M MiniModule gas contractor that separates the dissolved gas from the continuously pumped water (Schmidt et al., 2008). The gas was dried with a Drierite gas-drying unit, and analysed with a Durridge RAD7 radon detector (Burnett and Dulaiova, 2003). The ${ }^{222}$ Rn-in-water activity concentrations were calculated using the salinity and temperature dependent fractionation of ${ }^{222} \mathrm{Rn}$ between air and water (Schubert et al., 2012). The pressure, temperature, conductivity and optical dissolved oxygen sensors were manufactured by Sea $\&$ Sun 
Hydrol. Earth Syst. Sci. Discuss., https://doi.org/10.5194/hess-2018-507

Manuscript under review for journal Hydrol. Earth Syst. Sci.

Discussion started: 30 October 2018

Technology GmbH, the turbidity sensor by Seapoint Sensors Inc., and the ISM-2001C inductive 2D flow meter with compass by HS Engineers GmbH. The position was recorded by DGPS on the boat navigation system. Second, near-bottom water was measured at pockmark locations that were identified in the multibeam and side-scan sonar images. The frame that included the pumps and the CTD90M multiprobe was lowered to ca. $1 \mathrm{~m}$ above the seafloor, controlled by the boat echosounder and winch. The boat was anchored above the pockmarks, but drifted ca. 10 meters from side to side during the measurements because of wind. The near-bottom water was pumped and ${ }^{222} \mathrm{Rn}$ and the CTD90M parameters measured for at minimum 30 minutes at each location. In addition, a vertical water column profile was measured at $0.1 \mathrm{dbar}(\mathrm{ca} .10 \mathrm{~cm})$ intervals using the CTD90M multiprobe at each of the locations. Finally, groundwater was pumped from 8-10 m below the water table from the observation well HP101, and measured for ${ }^{222} \mathrm{Rn}$ activity concentration. Radon was also measured in

10 water that was gently leaking from the wall of an obsolete water station well near the shoreline. This groundwater ${ }^{222} \mathrm{Rn}$ activity concentrations were measured by using the 'soda bottle aerator' system (Durridge Inc.) in $500 \mathrm{ml}$ bottles, in conjunction with the RAD7 detector and the CAPTURE software for data evaluation.

Sediment cores were collected using a box corer from the pockmark locations where radon was measured. The cores were

15 visually inspected for sedimentary structures and grain size. The cores were cut in 1-cm sub-sample slices, which were analysed for Caesium-137 activity content in order to determine the amount of sediment in each core that was deposited after the fallout from the 1986 Chernobyl nuclear disaster. The ${ }^{137} \mathrm{Cs}$ activity content of fresh sub-samples was measured for 60 min using a BrightSpec bMCA-USB pulse height analyser coupled to a well-type NaI(Tl) detector at the Geological Survey of Finland. The same sub-samples were then analysed for weight loss on ignition (LOI), which is informative of sediment

20 organic content, by weighing sub-samples after drying at $105{ }^{\circ} \mathrm{C}$ for $16 \mathrm{~h}$ and weighing again after ignition at $550{ }^{\circ} \mathrm{C}$ for $2 \mathrm{~h}$ (Bengtsson and Enell, 1986).

\section{Results and interpretation}

\subsection{Offshore seismic units}

Seven seismic units (SUs) are recognized in offshore sub-bottom profiles that were collected along shore-normal transects 25 and along the shore platform edge (Fig. 2a). The denser units SU1-SU3 are identified in the deeper-penetrating reflection seismic profiles (Figs. 3c, d), whereas the units SU4-SU7 of lower acoustic impedance are better visible in the CHIRP profiles (Figs. 3a, b). The pinger had poor penetration in this area, likely because of the high sand content in the sediments.

\subsubsection{SU1: Bedrock}

Description. - SU1 is the seismic substratum (Fig. 3d). In the reflection seismic profiles, its upper reflector is an irregular, steep-relief unconformity surface, whereas the internal reflector configuration is chaotic. 
Hydrol. Earth Syst. Sci. Discuss., https://doi.org/10.5194/hess-2018-507

Manuscript under review for journal Hydrol. Earth Syst. Sci.

Discussion started: 30 October 2018

Interpretation. - The irregular surface and chaotic internal reflector configuration are consistent with crystalline bedrock. Palaeoproterozoic crystalline rocks dominate the bedrock in the study area (Kielosto et al., 1996).

\subsubsection{SU2: Till}

Description. - SU2 covers the substratum as a thin layer, and is generally less than $3 \mathrm{~m}$ thick, but may reach up to $10 \mathrm{~m}$ in

5 local depressions of the substratum (Fig. 3d). In the reflection seismic profiles, its upper reflector is an irregular unconformity surface with high amplitude. The internal reflector configuration is chaotic to locally stratified.

Interpretation. - The chaotic to locally stratified internal reflector configuration indicates massive deposits with little or no stratification and local stratified pockets, consistent with subglacial till (Eyles et al., 1985; Powell and Cooper, 2002). The

10 stratified pockets were produced by local meltwater processes. Similar surface reflector and external form have been reported for subglacial till in the neighbouring sea areas (Häkkinen, 1990; Rantataro, 1992; Nuorteva, 1994; Virtasalo et al., 2014). In the nearby land areas, the till thickness typically is less than $4 \mathrm{~m}$, but can reach $40 \mathrm{~m}$ in bedrock depressions and till landforms (Kielosto et al., 1996).

\subsubsection{SU3: Ice-contact subaqueous fan distal foreset}

15 Description. - SU3 is present along the west-north (ice-proximal) margin of the survey area (Fig. 2a). It has a wedge-shaped external form with the highest thickness of up to $6 \mathrm{~m}$ along the shore-parallel margin of the survey area, but which rapidly thins out with distance from the shore. In reflection seismic profiles, it is characterized by sub-parallel discontinuous reflectors that have lower amplitude than SU1 and SU2 (Figs. 3c, d).

20 Interpretation. - The low amplitude reflectors indicate finer grained sediments than in SU2, perhaps sand or fine sand. The discontinuity of internal reflectors indicates weak stratification. The stratigraphical position immediately above till, as well as the proximity and increasing unit thickness toward the First Salpausselkä ice-marginal formation indicate glaciofluvial origin for the sandy deposit. SU3 is interpreted to comprise distal foreset and possibly bottomset beds of an ice-contact subaqueous fan that is part of the First Salpausselkä (Virkkala, 1963; Glückert, 1986; Fyfe, 1990; Kujansuu et al., 1993). The poorly stratified fine sand beds were deposited by turbidity currents and occasional debris flows from the upper fan slope (Winsemann et al., 2009; Lang and Winsemann, 2013; Lang et al., 2017; Winsemann et al., 2018).

\subsubsection{SU4: Glaciolacustrine rhythmite}

Description. - In CHIRP profiles, SU4 is characterized by a lower part with sub-parallel discontinuous reflectors, and an upper part with closely spaced parallel reflectors of high amplitude (Figs 3a, b). The upper parallel reflectors in general are

30 parallel to reflectors in the overlying SU3, which indicates no significant erosion at the contact. On topographic highs, however, the SU4 reflector structure is truncated at the top, indicating erosion. 
Hydrol. Earth Syst. Sci. Discuss., https://doi.org/10.5194/hess-2018-507

Manuscript under review for journal Hydrol. Earth Syst. Sci.

Discussion started: 30 October 2018

Interpretation. - The poorly stratified lower part of SU4 in CHIRP profiles probably reflects high sand content, whereas the closely spaced parallel reflectors in the upper part of SU4 are typical of rhythmically alternating, glaciolacustrine fine sandsilt and clay layer couplets deposited by underflows and suspension settling during seasonal changes in glacial melting and sediment influx (De Geer, 1912; Sauramo, 1923; Eyles et al., 1985; Powell and Cooper, 2002; Virtasalo et al., 2007, 2014). The overall upward trend of fining grain size reflects the ice margin retreat.

\subsubsection{SU5: Postglacial lake clay}

Description. - SU5 forms a conformal drape with a constant thickness of 2-3 m, but is truncated at the top by erosion above topographic highs (Figs. 3a, b). In CHIRP profiles, it is characterized by closely spaced parallel reflectors reminiscent of

10 SU4, but with lower amplitudes and slightly smoother reflector angles due to the levelling of the underlying topography by SU4. The top boundary is a strong reflector.

Interpretation. - The drape-like geometry indicates deposition in deep water with limited reworking by near-bottom currents. The low-amplitude closely-spaced parallel reflector structure indicates weakly bedded to structureless fine-grained sediment, typical of the postglacial lake silty clay (Virtasalo et al., 2007, 2014).

\subsubsection{SU6 and SU7: Brackish-water mud drifts}

Description. - SU6 and SU7 have a similar asymmetric basin-fill external form, and frequent, low-amplitude, convex to onlap parallel reflectors in CHIRP profiles (Figs. 3a, b). Both units have strong basal reflectors, and their reflector structure is frequently truncated at the top by erosion. SU6 is widely distributed, whereas SU7 is present on top of SU6 in topographic depressions. SU7 has slightly smoother reflector angles due to the levelling of the underlying topography by SU6. The thickness of the units is variable, but both may reach $10 \mathrm{~m}$ in depressions. Attenuation (absorption and scattering) of the acoustic signal by free gas within the sediment (acoustic blanking) is common in areas of the highest unit thickness.

Interpretation. - The asymmetric external form and the convex to onlap reflector configuration reflect sediment-drift deposition that is controlled by currents and wave action, typical of the Baltic Sea brackish-water mud (Virtasalo et al., 2007). The basal reflector of SU6 is distinctive, and in fact traceable long distances in seismic profiles over the Baltic Sea (Virtasalo et al., 2016). The unconformity that subdivides the brackish-water muds into SU6 and SU7 with different internal reflector angles results from a shift in the lateral accretion of sediment due to land uplift and changed near-bottom current patterns. Similar unconformities within the brackish-water mud drift have been reported previously from the neighbouring sea areas (Virtasalo et al., 2007, 2014). 
Hydrol. Earth Syst. Sci. Discuss., https://doi.org/10.5194/hess-2018-507

Manuscript under review for journal Hydrol. Earth Syst. Sci.

Discussion started: 30 October 2018

\subsection{Ground-penetrating radar units}

Three radar units (RUs) are recognized in the onshore GPR profiles, which were recorded along survey lines that were oriented to continue the offshore seismic survey lines, and along perpendicular survey lines that followed the arc-shaped shoreline and the shore parallel road 500-800 m inland (Fig. 2a). The penetration depth of the GPR electromagnetic wave in

5 the studied deposits is ca. $12 \mathrm{~m}$ (Fig. 4a). The available drill logs from the survey area show, however, that the crystalline bedrock can be buried as much as $50 \mathrm{~m}$ below the land surface. The GPR profiles, therefore, capture only the upper part of the sandy overburden. The groundwater table is observable as a high-amplitude continuous reflector, which is at the sea level in the seaward ends of the profiles, but rises to ca. $12 \mathrm{~m}$ a.s.l. within $1 \mathrm{~km}$ distance to the shoreline. The groundwater is hosted in the unit RU1.

\section{4.2.1 RU1: Ice-contact subaqueous fan foreset}

Description. - The upper 8-12 m of RU1 is visible in the GPR profiles, below which depth the GPR electromagnetic wave is attenuated (Figs. 4a, b). The internal reflector configuration is highly variable in the northwestern (ice-proximal) part of the profiles, being characterized by lenticular and sheet-like reflector packages with local northwest and frequent southeast gently to steeply dipping reflectors of low to high amplitude. The reflector packages have unconformable contacts. In the

15 southeastern (ice-distal) parts of the profiles, the unit is dominated by steeply southeast dipping oblique low-amplitude reflectors. The internal reflector configuration of RU1 is truncated from the top by the basal reflector surface of RU2.

Interpretation. - The highly variable internal reflector configuration of RU1 with lenticular and sheet-like packages is similar to the distal sand-rich parts of ice-contact subaqueous fans (Winsemann et al., 2009; Lang and Winsemann, 2013; Lang et

20 al., 2017; Winsemann et al., 2018). The northwestern (upflow) parts of RU1 reflect dynamic net deposition of antidune and cyclic-step deposits by supercritical and subcritical turbidity currents, possibly of type foreset-bed packages III by Winsemann et al. (2018). Local high-amplitude reflectors indicate gravelly interbeds and lenses in the sand-dominated deposit. The sandy composition with gravel and coarse sand interlayers is confirmed by available drill logs from the survey area. The steeply downflow dipping oblique low-amplitude reflectors that dominate the southeastern (ice-distal) parts of the 25 profiles document fine sand-dominated steeply-inclined foreset clinoforms, presumably deposited from sustained supercritical turbidity currents (Winsemann et al., 2009; Lang and Winsemann, 2013; Lang et al., 2017; Winsemann et al., 2018). It is worth noting that the thickness of sandy deposits in the available drill logs can reach $50 \mathrm{~m}$, and that only their upper part was imaged in the GPR profiles.

\subsubsection{RU2: Shoreface lag deposit}

30 Description. - RU2 is a thin, $<2 \mathrm{~m}$ thick sheet that is characterized by high-amplitude sub-horizontal discontinuous reflectors (Figs. 4a, b). The reflectors downlap onto the basal reflection surface to RU1. 
Hydrol. Earth Syst. Sci. Discuss., https://doi.org/10.5194/hess-2018-507

Manuscript under review for journal Hydrol. Earth Syst. Sci.

Discussion started: 30 October 2018

Interpretation. - The sheet-like geometry and high-amplitude sub-horizontal downlapping internal reflectors indicate a coarse shoreface lag deposit, likely composed of gravel (Tamura et al., 2008). Such a deposit was formed by wave, current and winter-ice reworking of the primary ice-contact fan deposits (RU1) during emergence from the sea (Virkkala, 1963; Glückert, 1986; Fyfe, 1990; Kujansuu et al., 1993; Nemec et al., 1999).

\subsubsection{RU3: Beach ridges}

Description. - RU3 is the uppermost reflector unit that covers most of the land surface. It has an asymmetric external form, with the unit thickness varying from below the GPR resolution to as much as $6 \mathrm{~m}$ in large ridges (Figs. 4a, b). The internal reflection configuration is characterized by low-amplitude gently seaward dipping sub-parallel reflectors, and local landward dipping reflectors on the landward sides of large ridges. The reflectors downlap onto the top reflection surface of RU2.

Interpretation. - Beach ridges typically are dominated by seaward dipping sub-parallel reflectors, and local landward dipping reflectors on their landward sides. The seaward dipping sub-parallel reflectors represent sand with gravel interbeds, which were deposited at beachface by wave swash and backswash, whereas the local landward dipping reflectors on the landward sides of the ridges represent aeolian sands (Clemmensen and Nielsen, 2010; Rosentau et al., 2013; Muru et al., 2018).

\subsection{Refraction seismic profile}

The $900 \mathrm{~m}$ long refraction seismic profile was collected along the shoreline, on the sandy beach (Fig. 2a). A refraction surface at the depth of ca. $50 \mathrm{~m}$ in the western part of the profile rises to ca. $20 \mathrm{~m}$ depth in the eastern part of the profile (Fig. $4 c)$. This surface is interpreted to be the bedrock surface that is unconformably overlain by the glacial sediments. This interpretation is in line with the available drill logs from the area, which show that the bedrock can be buried as much as 50 $\mathrm{m}$ deep. Another refraction surface at sea level is interpreted to be the groundwater table.

\subsection{Seafloor morphology and pockmarks}

Multibeam bathymetry over the survey area shows a gently rolling seafloor with water depths ranging between 5 to $25 \mathrm{~m}$ (Fig. 2b). The seafloor is covered with brackish-water mud (SU7), except erosional exposures of till (SU2) at small

25 elevations in the southwestern and eastern parts of the area. An arc-shaped shore platform with sandy sediment extends 100$250 \mathrm{~m}$ seaward from the shoreline, sloping gently to ca. $4 \mathrm{~m}$ water depth (Fig. 2b). From the platform edge, the seafloor slopes to ca. $17 \mathrm{~m}$ depth within ca. $50 \mathrm{~m}$ distance. The shore platform was too shallow for $\mathrm{r} / \mathrm{v}$ Geomari to navigate, and therefore no seismoacoustic surveys were carried out there.

30 Multibeam image shows many as much as $25 \mathrm{~m}$ wide and up to $2 \mathrm{~m}$ deep pockmarks on the shore platform slope and at the base of the slope at down to ca. $17 \mathrm{~m}$ water depth (Fig. 2b). In CHIRP profiles, the pockmarks are incised in the topmost unit 
Hydrol. Earth Syst. Sci. Discuss., https://doi.org/10.5194/hess-2018-507

Manuscript under review for journal Hydrol. Earth Syst. Sci.

Discussion started: 30 October 2018

SU7 (Fig. 5d). Sub-vertical columns of disrupted reflectors, which are interpreted to be groundwater conduits, extend down from the pockmark base through SU7-SU5 to the upper well-stratified part of SU4 (glaciolacustrine rhythmites), at least. The seismic signal is attenuated below this stratigraphical level, likely because of the higher sediment sand content, and the full vertical extents of the disrupted reflector columns are unclear in the profiles. The columns tend to be localized at elevations in the SU4 top, which may have acted as natural leak-off points for overpressured pore fluids (Cartwright et al., 2007). Reflectors are commonly folded up along the column margins in SU4 and SU5, in line with upward fluid flow. In the upper part of SU6 and in SU7 (brackish-water mud drifts), however, the reflectors are folded down along column margins, recording the upward migration of pockmark base with sediment deposition (Cartwright et al., 2007).

10 The box-core sediment sample MGBC-2018-2 collected from the pockmark D is composed of structureless fine sand with very low organic content (Fig. 6a). The sample MGBC-2018-1 from the pockmark B is very similar. In contrast, the sample MGBC-2018-3 collected from the pockmark E is covered with a $7 \mathrm{~cm}$ thick surface layer of organic-rich mud, which is underlain by structureless fine sand of very low organic content (Fig. 6b). The surface of MGBC-2018-3 is overgrown by sea grass. Caesium-137 activity contents in the sand in MGBC-2018-3 are below $20 \mathrm{~Bq} / \mathrm{kg}$, which is a normal level for

15 sediments deposited before the 1986 Chernobyl nuclear disaster, whereas the ${ }^{137} \mathrm{Cs}$ contents are substantially higher in the surficial mud layer (range 27.9-44.2 Bq/kg). However, these values are still low compared to the present values exceeding $1,000 \mathrm{~Bq} / \mathrm{kg}$ in sediments that were deposited off the Finnish south coast soon after the disaster (e.g., Jokinen et al., 2015; Vallius, 2015). It appears that the ${ }^{137} \mathrm{Cs}$-enriched mud layer that covers the pockmark E was deposited sometime after 1986, possibly within the past several years.

\section{$20 \quad 4.5$ Hydrographic and radon measurements}

Profiles measured by the CTD90M multiprobe show that the seawater is stratified with respect to temperature, with the thermocline located at the 5-8 m depth (Figs. 5a-c). The temperature range is $13.2-15.9{ }^{\circ} \mathrm{C}$ in the upper water layer, and $7.8-10.2{ }^{\circ} \mathrm{C}$ in the bottom layer. The salinity range is $4.61-5.13 \mathrm{PSU}$ in the upper layer, whereas the bottom layer has a narrower range of 5.44-5.54 PSU. The water mass is well oxygenated with generally higher values in the bottom layer.

25

The mean ${ }^{222} \mathrm{Rn}$ activity concentration in the seawater surface is $16.9 \mathrm{~Bq} / \mathrm{m}^{3}$, with locally slightly elevated concentrations of up to $49.9 \mathrm{~Bq} / \mathrm{m}^{3}$ near the shoreline (Fig. 2c; Table 1). These elevated concentrations may result from localized groundwater seepage through the beach sand and/or from the local upwelling of ${ }^{222} \mathrm{Rn}$-bearing water from below the thermocline.

30 Significantly higher ${ }^{222} \mathrm{Rn}$ activity concentrations were measured ca. $1 \mathrm{~m}$ above the bottom at pockmarks D and B (134.7 and 156.9 Bq/m $\mathrm{m}^{3}$, respectively; Figs. 5b, c; Table 1). Above the pockmark B, an elevated ${ }^{222} \mathrm{Rn}$ concentration $\left(39.5 \mathrm{~Bq} / \mathrm{m}^{3}\right)$ was measured in the upper part of thermocline at $5.1 \mathrm{~m}$ water depth, and a concentration of $21.8 \mathrm{~Bq} / \mathrm{m}^{3}$ was measured at $1.5 \mathrm{~m}$ water depth, which is in the range of surface seawater concentrations. Apparently, the thermocline reduces the mixing of 
Hydrol. Earth Syst. Sci. Discuss., https://doi.org/10.5194/hess-2018-507

Manuscript under review for journal Hydrol. Earth Syst. Sci.

Discussion started: 30 October 2018

${ }^{222} \mathrm{Rn}$-enriched bottom waters with surface waters. Notably, ${ }^{222} \mathrm{Rn}$ concentrations measured ca. 1 and $2 \mathrm{~m}$ above the bottom of pockmark E (47.9 and $21.5 \mathrm{~Bq} / \mathrm{m}^{3}$, respectively) are in the range of seawater surface and thermocline concentrations, and significantly lower than at the pockmarks B and D. Therefore, ${ }^{222} \mathrm{Rn}$ measurements indicate no recent SGD from the pockmark E because the measured concentrations may result from ${ }^{222} \mathrm{Rn}$ diffusion from sediments and/or advection. Flow

5 directions measured below the thermocline at the pockmark E (Fig. 5a) range between west and north, which makes ${ }^{222} \mathrm{Rn}$ advection from the pockmarks D and B in the west likely.

Radon activity concentrations in groundwater, measured in the observation well HP101 $\left(12129 \mathrm{~Bq} / \mathrm{m}^{3}\right)$ and in the obsolete water station that is located $7 \mathrm{~m}$ inland from the shoreline $\left(37433 \mathrm{~Bq} / \mathrm{m}^{3}\right)$, are substantially higher than those measured in 10 seawater (Table 1).

\section{Discussion}

A multifaceted dataset comprising offshore seismic sub-bottom profiles, multibeam and sidescan sonar images of the seafloor, radon measurements of sea and groundwater, as well as onshore GPR and refraction seismic profiles has been studied with an aim to reconstruct the detailed stratigraphical architecture and aquifer geometry of a SGD site in the First

15 Salpausselkä ice-marginal formation on the Hanko Peninsula in Finland.

\subsection{Allostratigraphical architecture}

Marine seismic reflection and onshore GPR profiling methods are similar in that both are based on wave propagation through water and sediments, and on wave reflection from subsurface structures and boundaries. However, they are different in the type of wave used for profiling. Seismic wave is reflected from interfaces where the acoustic impedance of sediment

20 sharply changes (e.g. Sheriff and Geldart, 1995), whereas the GPR electromagnetic wave is sensitive to water content and the ability of sedimentary structures and layers to hold water governs GPR reflections (Annan, 2009). The seismic refraction method is different from the reflection methods in that the seismic wave returns to the surface by refraction at subsurface interfaces with a strong acoustic impedance contrast (e.g. Sheriff and Geldart, 1995). Because of the technological differences, profiles obtained by these methods record different properties of the subsurface, and, therefore, are not intercomparable. Significant unconformities in sediments, however, are typically associated with a change in the sediment acoustic impedance and water content, which is expressed in the different profiles by strong reflectors that can be correlated between the profiles following the allostratigraphical approach.

The use of allostratigraphy is recommended for glacial and glacially-influenced strata, which typically have frequent 30 unconformities and high lithological heterogeneity that complicates lithostratigraphical classification (e.g. Virtasalo et al., 2007, 2014; Räsänen et al., 2009). Indeed, sediment deposition and erosion in the study area have been controlled by several 
Hydrol. Earth Syst. Sci. Discuss., https://doi.org/10.5194/hess-2018-507

Manuscript under review for journal Hydrol. Earth Syst. Sci.

Discussion started: 30 October 2018

independent processes, namely the retreat of the Fennoscandian continental ice-sheet and the dynamics of the ice margin, the relative water level fall due to postglacial land uplift, the mid-Holocene marine incursion and the associated short-lived transgression and the establishment of brackish-water conditions, and, finally, coastal and aeolian processes (Virkkala, 1963; Glückert, 1986; Fyfe, 1990; Kujansuu et al., 1993; Virtasalo et al., 2007, 2014, 2016). As a result of the complex depositional history, allostratigraphy has recently gained popularity as a stratigraphical classification approach both in the Baltic Sea (e.g. Virtasalo et al., 2007, 2014; Tsyrulnikov et al., 2012; Hyttinen et al., 2017; Jensen et al., 2017) and on the surrounding land areas (Räsänen et al., 2009; Ojala et al., 2018).

In this study, allostratigraphy is used, for the first time, for the correlation of unconformities recognized in offshore seismic

10 profiles to those in onshore GPR and refraction seismic profiles in order to establish the local stratigraphic architecture cross the shoreline. Five significant unconformities are recognized in the offshore seismic profiles (Fig. 3), whereas two are recognized in the onshore GPR profiles and one in the refraction seismic profile (Fig. 4). The offshore unconformities are correlated with those onshore based on the interpreted composition and sedimentary environment of their bounded units (Fig. 7).

15

The lowermost unit with identifiable bottom and top reflectors in the offshore reflection seismic profiles is till (SU2; Fig. 3). The till layer is not discernible in the GPR profiles (Fig. 4a, b), which may be due to the insufficient depth penetration of the electromagnetic wave, or to the low thickness or even absence of the till layer because of the higher bedrock elevation on the land area. Likewise, no surface that could be associated with a till layer covering the bedrock is observed in the refraction 20 seismic profile (Fig. 4c). Geological mapping shows that bedrock elevations in the area often lack till cover (Kujansuu et al., 1993). Furthermore, unpublished drill logs of eight groundwater observation wells in the study area document no till layer on the bedrock.

The only unit that can be traced from the offshore seismic profiles to the onshore GPR profiles is the ice-contact subaqueous fan foreset on land (RU1) and its distal part offshore (SU3; Fig. 7). Such ice-contact subaqueous fans form a significant part of the First Salpausselkä ice-marginal formation (Virkkala, 1963; Glückert, 1986; Fyfe, 1990; Kujansuu et al., 1993). The unit is erosionally exposed at seafloor on the shore platform.

The glaciolacustrine, postglacial lacustrine and lower brackish-water deposits (SU4 to SU6) were deposited over the whole 30 study area (Virtasalo et al., 2007; 2014), but have since been removed from the GPR-profiled land area as a consequence of erosion by waves, currents and winter-ice during emergence from the sea. The coarse lag sheet (RU2) in the GPR profiles is the product of this erosion and associated preferential removal of fine grained material. The overlying beach ridge deposits (RU3) were formed at the beachface during emergence and by later aeolian processes. The upper brackish-water mud unit (SU7) represents modern drift deposition at sea. 
Hydrol. Earth Syst. Sci. Discuss., https://doi.org/10.5194/hess-2018-507

Manuscript under review for journal Hydrol. Earth Syst. Sci.

Discussion started: 30 October 2018

\subsection{Submarine groundwater discharge}

The main coastal aquifer on the Hanko Peninsula is hosted in the First Salpausselkä ice-marginal formation (e.g. Luoma et al., 2015), which is a ridge of contiguous ice-contact subaqueous fans and local feeding eskers (Virkkala, 1963; Glückert, 1986; Fyfe, 1990; Kujansuu et al., 1993). The studied SGD site is situated in the foreset of a subaqueous fan (RU1-SU3; Fig.

5 7). Based on low reflector amplitudes in the offshore seismic profiles (SU3; Figs. 3c, d) and available unpublished drill logs from the land area, the subaqueous fan foreset is composed of fine sand, which typically has moderate hydraulic conductivity (e.g. Bear, 1972). However, GPR profiles and the drill logs show interbeds and lenses of coarse sand and gravel in the subaqueous fan foreset. Slug tests carried out in the area demonstrate high hydraulic conductivities for such coarser beds (K $<13.8 \mathrm{~m} / \mathrm{d}$; Luoma and Pullinen, 2011). It is thus likely that the coarser interbeds and lenses in the fine sand-dominated

10 subaqueous fan foreset provide conduits for localized groundwater flow to pockmarks that are visible on the shore platform slope (Figs. 2b, 2d). In addition, coarse couplet layers in the superimposed glaciolacustrine rhythmite can act as groundwater conduits to the pockmarks (Söderberg and Flodén, 1997; Virtasalo et al., 2007). The offshore stratigraphical units the till (SU2), postglacial lacustrine poorly-bedded silty clay (SU5), and organic-rich brackish-water mud (SU6 and SU7) have low hydraulic conductivities, and the silty clay and mud units likely act as confining layers (e.g. Bear, 1972).

15

Significantly elevated radon activity concentrations measured $1 \mathrm{~m}$ above the pockmarks D and B indicate SGD from these locations (Figs. 4b, c). In comparison, ${ }^{222} \mathrm{Rn}$ concentrations measured above the pockmark $\mathrm{E}$ are not elevated but similar to those measured in the thermocline above the pockmark D and in surface seawater (Figs. 2c, 4a; Table 1), which precludes significant SGD from the pockmark $\mathrm{E}$ at the time of measurements. It can thus be concluded that pockmarks are the most

20 significant locations of SGD in the study area, and that not all of the pockmarks observed in the multibeam and sidescan sonar images are active. ${ }^{222} \mathrm{Rn}$ has been previously used for studying SGD from pockmarks in the Eckernförde Bay, southern Baltic Sea (Schlüter et al., 2004).

In order to roughly estimate the rate of SGD from the pockmark B, the ${ }^{222} \mathrm{Rn}$ inventory of $\sim 781 \mathrm{~Bq} / \mathrm{m}^{2}$ is calculated on the basis of concentration gradient between the pockmark B bottom and the thermocline upper boundary. Assuming steady state and that SGD is the only major source of radon, the calculated ${ }^{222} \mathrm{Rn}$ inventory will decay at the rate of $142 \mathrm{~Bq} / \mathrm{m}^{2} / \mathrm{d}$, which must be balanced by SGD. Using the measured ${ }^{222} \mathrm{Rn}$ concentrations of groundwater in the well HP 101 and the obsolete water station (Table 1) we arrive at SGD rates between 0.4 and $1.2 \mathrm{~cm} / \mathrm{d}$. This simple model does not consider the lateral export of ${ }^{222} \mathrm{Rn}$ due to bottom currents, for example. The ${ }^{222} \mathrm{Rn}$ inventory and SGD rates, therefore, must be considered as lower limits.

Sediment samples collected from the pockmarks D and B are composed of fine sand, whereas the pockmark E is covered with soft organic-rich mud (Fig. 6). Considering the lack of SGD from the pockmark E as demonstrated by the low ${ }^{222} \mathrm{Rn}$ 
Hydrol. Earth Syst. Sci. Discuss., https://doi.org/10.5194/hess-2018-507

Manuscript under review for journal Hydrol. Earth Syst. Sci.

Discussion started: 30 October 2018

activity concentrations, it would seem plausible that SGD prevents permanent organic-rich mud deposition in the pockmarks $\mathrm{D}$ and $\mathrm{B}$. Indeed, our unpublished video observations show that percolating subsurface fluids cause the resuspension of fine sediment in the pockmarks (see also Schlüter et al., 2004). The resuspended fine sediment is then removed by near-bottom flows, resulting in lower relative sedimentation rate and coarser grain size in the pockmark (Hammer et al., 2009). The absence of significantly elevated rims around the pockmarks (Fig. 5d) further supports the efficient lateral sediment transport and precludes significant subsurface sediment mobilization and transport of particles to the seafloor (Loher et al., 2016). ${ }^{137} \mathrm{Cs}$ activity contents in the organic-rich surface mud layer in the pockmark $\mathrm{E}$ are at the post-Chernobyl level (Fig. 6b), which suggests that SGD from the pockmark ceased several years after 1986. No faults are observed in the studied profiles, and the groundwater conduits do not seem to be linked with faulting.

10

SGD depends on the hydraulic head gradient between the elevated part of the aquifer on land, and the top of the permeable unit at sea (Burnett et al., 2003; Moore, 2010). The GPR profiles show that groundwater is hosted in the subaqueous fan deposits (RU1; Fig. 4). Seaward groundwater flow at the study area can have initiated only after the subaqueous fan deposits had been uplifted sufficiently high above sea level in order to produce the required hydraulic head. The change in the

15 direction of folding of reflectors along the margins of groundwater conduits from folded-up to folded-down in the upper part of SU6 in the CHIRP profiles indicates a shift from the post-depositional folding by upward fluid expulsion to the upward migration of the pockmark bottom with sediment deposition (Fig. 5d; Cartwright et al., 2007). This timing of the formation of pockmarks and the initiation of SGD must have taken place after the beginning of the brackish-water mud (SU6) deposition at ca. 7600 years ago (Virtasalo et al., 2007). According to shore displacement studies, the subaqueous fan

20 deposits that today rise as much as $20 \mathrm{~m}$ above sea level in the area, began to emerge from the sea ca. 5000 years ago (Eronen et al., 2001), which is in good agreement with the reflector-folding interpretation of CHIRP profiles. Probably it took several hundreds of years before the subaqueous fan deposits were uplifted sufficiently high above sea level for the initiation SGD and the formation of first pockmarks.

25 Radon activity concentrations measured in the groundwater observation well HP101 $\left(12129 \mathrm{~Bq} / \mathrm{m}^{3}\right)$ and in the obsolete water station $\left(37433 \mathrm{~Bq} / \mathrm{m}^{3}\right.$ ) are substantially higher than those measured in seawater (Table 1). The measured values are below the mean ${ }^{222} \mathrm{Rn}$ activity concentration of $92000 \mathrm{~Bq} / \mathrm{m}^{3}$ in 961 springs and dug wells in southern Finland (Salonen, 1988), and well below the upper permissible limit for ${ }^{222} \mathrm{Rn}$ in public drinking water in Finland that is set to $300000 \mathrm{~Bq} / \mathrm{m}^{3}$ (Ministry of Social Affairs and Health, 2001).

\section{Conclusions}

Allostratigraphical architecture and aquifer geometry have been established of a SGD site in the First Salpausselkä icemarginal formation on the Hanko Peninsula in Finland. Significant unconformities recognized in the offshore seismic and 
Hydrol. Earth Syst. Sci. Discuss., https://doi.org/10.5194/hess-2018-507

Manuscript under review for journal Hydrol. Earth Syst. Sci.

Discussion started: 30 October 2018

onshore GPR and refraction seismic profiles permitted the allostratigraphical correlation cross the shoreline. The studied location is characterized by a sandy beach, a sandy shore platform that extends $100-250 \mathrm{~m}$ seaward sloping gently to c. $4 \mathrm{~m}$ water depth, and a steep slope to c. $17 \mathrm{~m}$ water depth within ca. $50 \mathrm{~m}$ distance. The aquifer is hosted in the distal sanddominated part of an ice-contact subaqueous fan foreset with coarse sand and gravel interbeds and lenses. Presumably, the coarser interbeds and lenses in the distal foreset, and, potentially, coarse couplet layers in the overlying glaciolacustrine rhythmite, provide conduits for localized groundwater flow, which is discharged predominantly through pockmarks that are visible on the shore platform slope in multibeam and sidescan sonar images. Radon measurements confirmed SGD from the pockmarks D and B, while the pockmark $\mathrm{E}$ was inactive and covered by an organic-rich mud surface layer of several years. The SGD initiated after brackish-water conditions were established in the northern Baltic Sea, probably soon after 5000

10 years ago when the highest ice-contact fan deposits emerged above sea level as a result of postglacial land uplift.

\section{Data availability}

Hydrographic data, surface seawater ${ }^{222} \mathrm{Rn}$ activity concentration, LOI and ${ }^{137} \mathrm{Cs}$ results of sediment samples, and groundpenetrating radar profiles are available in a supplementary file to this paper.

\section{Author contribution}

15 Joonas Virtasalo devised the study, and was responsible of the offshore seismic surveys, hydrographic measurements and data interpretation. Jan Schröder and Jan Scholten were responsible of sea and groundwater radon measurements and data interpretation. Samrit Luoma participated in planning the study, and together with Juha Majaniemi collected and processed the GPR data. Juha Mursu was responsible of the collection and interpretation of refraction seismic data. Joonas Virtasalo prepared the manuscript with contributions from all co-authors.

Competing interests. The authors declare that they have no conflict of interest.

\section{Acknowledgements}

This work resulted from the BONUS SEAMOUNT project supported by BONUS (Art 185), funded jointly by the EU, the Academy of Finland (Grant No. 311983), and the Federal Ministry of Education and Research, Germany (Grant No.

25 03F0771B). This study has utilized research infrastructure facilities provided by FINMARI (Finnish Marine Research Infrastructure network). 
Hydrol. Earth Syst. Sci. Discuss., https://doi.org/10.5194/hess-2018-507

Manuscript under review for journal Hydrol. Earth Syst. Sci.

Discussion started: 30 October 2018

(c) Author(s) 2018. CC BY 4.0 License.

\section{References}

Andersen, J. H., Carstensen, J., Conley, D. J., Dromph, K., Fleming-Lehtinen, V., Gustafsson, B. G., Josefson, A. B., Norkko, A., Villnäs, A., and Murray, C.: Long-term temporal and spatial trends in eutrophication status of the Baltic Sea, 5 Biol. Rev., 92, 135-149, doi:10.1111/brv.12221, 2017.

Andrews, J. N. and Wood, D. F.: Mechanism of radon release in rock matrices and entry into groundwaters, T. I. Min.

Metall. B, 81, 197-209, 1972.

10 Annan, A. P.: Electromagnetic principles of ground penetrating radar, in: Ground Penetrating Radar: Theory and Applications, Jol, H. M. (ed.), Elsevier, Amsterdam, The Netherlands, 3-40, 2009.

Bengtsson, L. and Enell, M.: Chemical analysis, in: Handbook of Holocene Palaeoecology and Palaeohydrology, Berglund, D. E. (ed.), Wiley, Chichester, UK, 423-451, 1986.

15

Bear, J.: Dynamics of fluids in porous media, Elsevier, New York, U.S.A., 756 pp., 1972.

Burnett, W. C. and Dulaiova, H.: Estimating the dynamics of groundwater input into the coastal zone via continuous radon222 measurements, J. Environ. Radioactiv., 69, 21-35, doi:10.1016/S0265-931X(03)00084-5, 2003.

20

Burnett, W. C., Bokuniewicz, H., Huettel, M., Moore, W. S., and Taniguchi, M.: Groundwater and pore water inputs to the coastal zone, Biogeochemistry, 66, 3-33, doi:10.1023/B:BIOG.0000006066.21240.53, 2003.

Burnett, W. C., Peterson, R., Moore, W. S., and de Oliveira, J.: Radon and radium isotopes as tracers of submarine 25 groundwater discharge - Results from the Ubatuba, Brazil SGD assessment intercomparison, Estuar. Coast. Shelf S., 76, 501-511, doi:10.1016/j.ecss.2007.07.027, 2008.

Buynevich, I. V., Jol, H. M., and FitzGerald, D. M.: Coastal environments, in: Ground Penetrating Radar: Theory and Applications, Jol, H. M. (ed.), Elsevier, Amsterdam, The Netherlands, 299-322, 2009.

Cartwright, J., Huuse, M., and Aplin, A.: Seal bypass systems, AAPG Bull., 91, 1141-1166, doi:10.1306/04090705181, 2007. 
Hydrol. Earth Syst. Sci. Discuss., https://doi.org/10.5194/hess-2018-507

Manuscript under review for journal Hydrol. Earth Syst. Sci.

Discussion started: 30 October 2018

Clemmensen, L. B. and Nielsen, L.: Internal architecture of a raised beach ridge system (Anholt, Denmark) resolved by ground-penetrating radar investigations, Sediment. Geol., 223, 281-290, doi:10.1016/j.sedgeo.2009.11.014, 2010.

De Geer, G.: Geochronologie der letzten 12000 Jahre, Geol. Rundsch., 3, 457-471, doi:10.1007/BF01802565, 1912.

Eronen, M., Glückert, G., Hatakka, L., van de Plassche, O., van der Plicht, J., and Rantala, P.: Rates of Holocene isostatic uplift and relative sea-level lowering of the Baltic in SW Finland based on studies of isolation contacts, Boreas, 30, 17-30, doi:10.1111/j.1502-3885.2001.tb00985.x, 2001.

10 Eyles, C. H., Eyles, N., and Miall, A. D.: Models of glaciomarine sedimentation and their application to the interpretation of ancient glacial sequences, Palaeogeogr. Palaeocl., 51, 15-84, doi:10.1016/0031-0182(85)90080-X, 1985.

Ferguson, G. and Gleeson, T.: Vulnerability of coastal aquifers to groundwater use and climate change, Nat. Clim. Change, 2, 342-345, doi:10.1038/nclimate1413, 2012.

15

Fyfe, G. J.: The effect of water depth on ice-proximal glaciolacustrine sedimentation: Salpausselka I, southern Finland, Boreas, 19, 147-164, doi:10.1111/j.1502-3885.1990.tb00576.x, 1990.

Gleeson, J., Santos, I. R., Maher, D. T., and Golsby-Smith, L.: Groundwater-surface water exchange in a mangrove tidal 20 creek: evidence from natural geochemical tracers and implications for nutrient budgets, Mar. Chem., 156, 27-37, doi:10.1016/j.marchem.2013.02.001, 2013.

Glückert, G.: The First Salpausselkä at Lohja, southern Finland, Bull. Geol. Soc. Finland, 58, 45-55, 1986.

25 Häkkinen, A.: Saaristomeren vedenalaiset maa-ainesvarat, Varsinais-Suomen seutukaavaliitto, Turku, Finland, 58 pp., 1990.

Hammer, Ø., Webb, K. E., and Depreiter, D.: Numerical simulation of upwelling currents in pockmarks and data from the Inner Oslofjord, Norway, Geo-Mar. Lett., 29, 269-275, doi:10.1007/s00367-009-0140-z, 2009.

30 Hyttinen, O., Kotilainen, A. T., Virtasalo, J. J., Kekäläinen, P., Snowball, I., Obrochta, S., and Andrén, T.: Holocene stratigraphy of the Ångermanälven River estuary, Bothnian Sea, Geo-Mar. Lett., 37, 273-288, doi:10.1007/s00367-0160490-2, 2017. 
Hydrol. Earth Syst. Sci. Discuss., https://doi.org/10.5194/hess-2018-507

Manuscript under review for journal Hydrol. Earth Syst. Sci.

Discussion started: 30 October 2018

Jakobsson, M., O’Regan, M., Gyllencreutz, R., and Flodén, T.: Seafloor terraces and semi-circular depressions related to fluid discharge n Stockholm Archipelago, Baltic Sea, in: Atlas of Submarine Glacial Landforms: Modern, Quaternary and Ancient, Dowdeswell, J. A., Canals, M., Jakobsson, M., Todd, B. J., Dowdeswell, E. K., and Hogan, K. A. (eds.), Geological Society, London, Memoirs, 46, 305-306, doi:10.1144/M46.162, 2016.

Jankowska, H., Matciak, M., and Nowacki, J.: Salinity variations as an effect of groundwater seepage through the seabed (Puck Bay, Poland), Oceanologia, 36, 33-46, 1994.

Jensen, J. B., Kuijpers, A., Bennike, O., Laier, T., and Werner, F.: New geological aspects for freshwater seepage and formation in Eckernförde Bay, western Baltic, Cont. Shelf Res., 22, 2159-2173, doi:10.1016/S0278-4343(02)00076-6, 2002.

Jensen, J. B., Moros, M., Endler, R., and IODP Expedition 347 Members.: The Bornholm Basin, southern Scandinavia: a complex history from Late Cretaceous structural developments to recent sedimentation, Boreas, 46, 3-17, doi:10.1111/bor.12194, 2017.

15

Jokinen, S. A., Virtasalo, J. J., Kotilainen, A. T., and Saarinen, T.: Varve microfabric record of seasonal sedimentation and bottom flow-modulated mud deposition in the coastal northern Baltic Sea, Mar. Geol., 366, 79-96, doi:10.1016/j.margeo.2015.05.003, 2015.

20 Kakkuri, J.: Fennoscandian land uplift: past, present and future, in: From the Earth's Core to Outer Space, Haapala, I. (ed.), Lecture Notes in Earth System Sciences, 137, 127-136, doi:10.1007/978-3-642-25550-2_8, 2012.

Kielosto, S., Kukkonen, M., Stén, C.-G., and Backman, B.: Hangon ja Perniön kartta-alueiden maaperä. Summary: Quaternary deposits in the Hanko and Perniö map-sheet areas. Geological map of Finland 1:100 000. Explanation to the maps of Quaternary deposits, sheets 2011 and 2012, Geological Survey of Finland, Espoo, Finland, 104 pp., 1996.

Krall, L., Trezzi, G., Garcia-Orellana, J., Rodellas, V., Mörth, C.-M., and Andersson, P.: Submarine groundwater discharge at Forsmark, Gulf of Bothnia, provided by Ra isotopes, Mar. Chem., 196, 162-172, doi:10.1016/j.marchem.2017.09.003, 2017.

Kujansuu, R., Uusinoka, R., Herola, E., and Sten, C.-G.: Tammisaaren kartta-alueen maaperä. Summary: Quaternary deposits in the Tammisaari map-sheet area. Geological map of Finland 1:100 000. Explanation to the maps of Quaternary deposits, sheet 2014, Geological Survey of Finland, Espoo, Finland, 90 pp., 1993. 
Hydrol. Earth Syst. Sci. Discuss., https://doi.org/10.5194/hess-2018-507

Manuscript under review for journal Hydrol. Earth Syst. Sci.

Discussion started: 30 October 2018

Lang, J. and Winsemann, J.: Lateral and vertical facies relationships of bedforms deposited by aggradating supercritical flows: from cyclic steps to humpback dunes, Sediment. Geol., 296, 36-54, doi:10.1016/j.sedgeo.2013.08.005, 2013.

Lang, J., Sievers, J., Loewer, M., Igel, J., and Winsemann, J.: 3D architecture of cyclic-step and antidune deposits in 5 glacigenic subaqueous fan and delta settings: integrating outcrop and ground-penetrating radar data, Sediment. Geol., 362, 83-100, doi:10.1016/j.sedgeo.2017.10.011, 2017.

Loher, M., Reusch, A., and Strasser M.: Long-term pockmark maintenance by fluid seepage and subsurface sediment mobilization - sedimentological investigations in Lake Neuchâtel, Sedimentology, 63, 1168-1186, doi:10.1111/sed.12255, 102016.

Lønne, I.: Sedimentary facies and depositional architecture of ice-contact glaciomarine systems, Sediment. Geol., 98, 13-43, doi:10.1016/0037-0738(95)00025-4, 1995.

15 Luoma, S. and Okkonen, J.: Impacts of future climate change and Baltic Sea level rise on groundwater recharge, groundwater levels, and surface leakage in the Hanko aquifer in Southern Finland, Water, 6, 3671-3700, doi:10.3390/w6123671, 2014.

Luoma, S. and Pullinen, A.: Field Investigation and Estimates of Hydraulic Conductivity from Slug Tests in the First

20 Salpausselkä formation in the Santala area, Hanko, south Finland, Archived report, Geological Survey of Finland, Espoo, 2011.

Luoma, S., Okkonen, J., Korkka-Niemi, K., Hendriksson, N., and Backman, B.: Confronting the vicinity of the surface water and sea shore in a shallow glaciogenic aquifer in southern Finland, Hydrol. Earth Syst. Sci., 19, 1353-1370, doi:10.5194/hess-19-1353-2015, 2015.

Merkouriadi, I. and Leppäranta, M.: Long-term analysis of hydrography and sea-ice data in Tvärminne, Gulf of Finland, Baltic Sea, Climatic Change, 124, 849-859, doi:10.1007/s10584-014-1130-3, 2014.

30 Ministry of Social Affairs and Health: Decree 401/2001, Sosiaali- ja terveysministeriön asetus pienten yksiköiden talousveden laatuvaatimuksista ja valvontatutkimuksista, 2001.

Moore, W. S.: The effect of submarine groundwater discharge on the ocean, Annu. Rev. Mar. Sci., 2, 59-88, doi:10.1146/annurev-marine-120308-081019, 2010. 
Hydrol. Earth Syst. Sci. Discuss., https://doi.org/10.5194/hess-2018-507

Manuscript under review for journal Hydrol. Earth Syst. Sci.

Discussion started: 30 October 2018

Mullinger, N. J., Pates, J. M., Binley, A. M., and Crook, N. P.: Controls on the spatial and temporal variability of ${ }^{222} \mathrm{Rn}$ in riparian groundwater in a lowland Chalk catchment, J. Hydrol., 376, 58-69, doi:10.1016/j.jhydrol.2009.07.015, 2009.

Muru, M., Rosentau, A., Preusser, F., Plado, J., Sibul, I., Jõeleht, A., Bjursäter, S., Aunap, R., and Kriiska, A.: Reconstructing Holocene shore displacement and Stone Age palaeogeography from a foredune sequence on Ruhnu Island, Gulf of Riga, Baltic Sea, Geomorphology, 303, 434-445, doi:10.1016/j.geomorph.2017.12.016, 2018.

Neal, A.: Ground-penetrating radar and its use in sedimentology: principles, problems and progress, Earth-Sci. Rev., 66, 10 261-330, doi:10.1016/j.earscirev.2004.01.004, 2004.

Nemec, W., Lønne, I., and Blikra, L. H.: The Kregnes moraine in Gauldalen. west-central Norway: anatomy of a Younger Dryas proglacial delta in a palaeofjord basin, Boreas, 28, 454-476, doi:10.1111/j.1502-3885.1999.tb00234.x, 1999.

15 Nuorteva, J.: Topographically influenced sedimentation in Quaternary deposits - a detailed acoustic study from the western part of the Gulf of Finland, Geological Survey of Finland, Report of Investigation, 122, 1-88, 1994.

Ojala, A. E. K., Saresma, M., Virtasalo, J. J., and Huotari-Halkosaari, T.: An allostratigraphic approach to subdivide finegrained sediments for urban planning, B. Eng. Geol. Environ., doi:10.1007/s10064-016-0981-4, 2018.

Pellikka, H., Leijala, U., Johansson, M. M., Leinonen, K., and Kahma, K. K.: Future probabilities of coastal floods in Finland, Cont. Shelf Res., 157, 32-42, doi:10.1016/j.csr.2018.02.006, 2018.

Peterson, R. N., Burnett, W. C., Taniguchi, M., Chen, J., Santos, I. R., and Ishitobi, T.: Radon and radium isotope assessment 25 of submarine groundwater discharge in the Yellow River Delta, China, J. Geophys. Res., 113, C09021, doi:10.1029/2008JC004776, 2008.

Powell, R. D. and Cooper, J. M.: A glacial sequence stratigraphic model for temperate, glaciated continental shelves, in: Glacier-Influenced Sedimentation on High-Latitude Continental Margins, Dowdeswell, J. A., and Ó Cofaigh, C. (eds.), 30 Geological Society, London, Special Publications, 203, 215-244, doi:10.1144/GSL.SP.2002.203.01.12, 2002.

Prakash, R., Srinivasamoorthy, K., Gopinath, S., Saravanan, K., Vinnarasi, F., Ponnumani, G., Chidambaram, S., and Anandhan, P.: Radon isotope assessment of submarine groundwater discharge (SGD) in Coleroon River Estuary, Tamil Nadu, India, J. Radioanal. Nucl. Ch., 317, 25-36, doi:10.1007/s10967-018-5877-2, 2018. 
Hydrol. Earth Syst. Sci. Discuss., https://doi.org/10.5194/hess-2018-507

Manuscript under review for journal Hydrol. Earth Syst. Sci.

Discussion started: 30 October 2018

Rantataro, J.: Pääkaupunkiseudun edustan vedenalaiset maa-ainesvarat, Helsingin seutukaavaliiton julkaisuja, C31, 1-84, 1992.

5 Räsänen, M. E., Auri, J. M., Huitti, J. V., Klap, A. K., and Virtasalo, J. J.: A shift from lithostratigraphic to allostratigraphic classification of Quaternary glacial deposits, GSA Today, 19, 2, 4-11, doi:10.1130/GSATG20A.1, 2009.

Rinterknecht, V. R., Clark, P. U., Raisbeck, G. M., Yiou, F., Brook, E. J., Tschudi, S., and Lunkka, J. P.: Cosmogenic 10Be dating of the Salpausselkä I moraine in southwestern Finland, Quaternary Sci. Rev., 23, 2283-2289, 10 doi:10.1016/j.quascirev.2004.06.012.

Rosentau, A., Joeleht, A., Plado, J., Aunap, R., Muru, M., and Eskola, K. O.: Development of the Holocene foredune plain in the Narva-Joesuu area, eastern Gulf of Finland, Geol. Q., 57, 89-100, doi:10.7306/gq.1077, 2013.

15 Saarnisto, M. and Saarinen, T.: Deglaciation chronology of the Scandinavian Ice Sheet from the Lake Onega Basin to the Salpausselkä end moraines, Global Planet. Change, 31, 387-405, doi:10.1016/S0921-8181(01)00131-X, 2001.

Sadat-Noori, M., Santos, I. R., Sanders, C. J., Sanders, L. M., and Maher, D. T.: Groundwater discharge into an estuary using spatially distributed radon time series and radium isotopes, J. Hydrol., 528, 703-719, doi:10.1016/j.jhydrol.2015.06.056, 202015 .

Salonen, L.: Natural radionuclides in ground water in Finland, Radiat. Prot. Dosim., 24, 163-166, doi: 10.1093/oxfordjournals.rpd.a080263, 1988.

25 Sauramo, M.: Studies on the Quaternary varve sediments in southern Finland, Bulletin de la Commission géologique de Finlande, 60, 1-164, 1923.

Schlüter, M., Sauter, E. J., Andersen, C. E., Dahlgaard, H., and Dando, P. R.: Spatial distribution and budget for submarine groundwater discharge in Eckernförde Bay (western Baltic Sea), Limnol. Oceanogr., 49, 157-167, 30 doi:10.4319/lo.2004.49.1.0157, 2004.

Schmidt, A., Schlueter, M., Melles, M., and Schubert, M.: Continuous and discrete on-site detection of radon-222 in groundand surface waters by means of an extraction module, Appl. Radiat. Isotopes, 66, 1939-1944, doi:10.1016/j.apradiso.2008.05.005, 2008. 
Hydrol. Earth Syst. Sci. Discuss., https://doi.org/10.5194/hess-2018-507

Manuscript under review for journal Hydrol. Earth Syst. Sci.

Discussion started: 30 October 2018

Schubert, M., Paschke, A., Lieberman, E., and Burnett, W. C.: Air-water partitioning of ${ }^{222} \mathrm{Rn}$ and its dependence on water temperature and salinity, Environ. Sci. Technol., 46, 3905-3911, doi:10.1021/es204680n, 2012.

5 Schubert, M., Scholten, J., Schmidt, A., Comanducci, J. F., Pham, M. K., Mallast, U., and Knoeller, K.: Submarine groundwater discharge at a single spot location: evaluation of different detection approaches, Water, 6, 584-601, doi:10.3390/w6030584, 2014.

Sheriff, R. E. and Geldart, L.P.: Exploration seismology, Cambridge University Press, Cambridge, UK, 592 pp., 1995.

10

Söderberg, P. and Flodén, T.: Stratabound submarine terraces and pockmarks - indicators of spring sapping in glacial clay, Stockholm Archipelago, Sweden, Sveriges Geologiska Undersökning, Ser. Ca 86, 173-178, 1997.

Sviridov, N. I. 1977: Results of sound velocity measurements in the Baltic Sea bottom sediments, Baltica, 6, 173-180.

15

Szymczycha, B., Vogler, S., and Pempkowiak, J.: Nutrient fluxes via submarine groundwater discharge to the Bay of Puck, southern Baltic Sea, Sci. Total Environ., 438, 86-93, doi: 10.1016/j.scitotenv.2012.08.058, 2012.

Szymczycha, B., Kroeger, K. D., and Pempkowiak, J.: Significance of groundwater discharge along the coast of Poland as a

20 source of dissolved metals to the southern Baltic Sea, Mar. Pollut. Bull., 109, 151-162, doi:10.1016/j.marpolbul.2016.06.008, 2016.

Tamura, T., Murakami, F., Nanayama, F., Watanabe, K., and Saito, Y.: Ground-penetrating radar profiles of Holocene raised-beach deposits in the Kujukuri strand plain, Pacific coast of eastern Japan, Mar. Geol., 248, 11-27, doi:10.1016/j.margeo.2007.10.002, 2008.

Tait, D. R., Santos, I. R., Erler, D. V., Befus, K. M., Cardenas, M. B., and Eyre, B. D.: Estimating submarine groundwater discharge in a South Pacific coral reef lagoon using different radioisotope and geophysical approaches, Mar. Chem., 156, 49-60, doi:10.1016/j.marchem.2013.03.004, 2013.

Tsyrulnikov, A., Tuuling, I., Kalm, V., Hang, T., and Flodén, T.: Late Weichselian and Holocene seismostratigraphy and depositional history of the Gulf of Riga, NE Baltic Sea, Boreas, 41, 673-689, doi:10.1111/j.1502-3885.2012.00257.x, 2012. 
Hydrol. Earth Syst. Sci. Discuss., https://doi.org/10.5194/hess-2018-507

Manuscript under review for journal Hydrol. Earth Syst. Sci.

Discussion started: 30 October 2018

Vallius, H.: Sediment and carbon accumulation rates off the southern coast of Finland, Baltica, 28, 81-88, doi:10.5200/baltica.2015.28.08, 2015.

Virkkala, K.: On ice-marginal features in southwestern Finland, Bulletin de la Commission géologique de Finlande, 210, 1$576,1963$.

Virtasalo, J. J., Kotilainen, A. T., Räsänen, M. E., and Ojala, A. E. K.: Late-glacial and post-glacial deposition in a large, low relief, epicontinental basin: the northern Baltic Sea, Sedimentology, 54, 1323-1344, doi:10.1111/j.1365-3091.2007.00883.x, 2007.

10

Virtasalo, J. J., Hämäläinen, J., and Kotilainen, A. T.: Toward a standard stratigraphical classification practice for the Baltic Sea sediments: the CUAL approach, Boreas, 43, 924-938, doi:10.1111/bor.12076, 2014.

Virtasalo, J. J., Endler, M., Moros, M., Jokinen, S. A., Hämäläinen, J., and Kotilainen, A.T.: Base of brackish-water mud as

key regional stratigraphic marker of mid-Holocene marine flooding of the Baltic Sea Basin, Geo-Mar. Lett., 36, 445-456, doi:10.1007/s00367-016-0464-4, 2016.

Winsemann, J., Aspirion, U., and Meyer, T.: Lake-level control on ice-margin subaqueous fans, glacial Lake Rinteln, northwest Germany, in: Glacial Sedimentary Processes and Products, Hambrey, M. J., Christoffersen, P., Glasser, N. F., and Hubbard, B. (eds.), Blackwell Publishing, Oxford, UK, 121-148, doi:10.1002/9781444304435.ch9, 2009.

Winsemann, J., Lang, J., Polom, U., Loewer, M., Igel, J., Pollok, L., and Brandes, C.: Ice-marginal forced regressive deltas in glacial lake basins: geomorphology, facies variability and large-scale depositional architecture, Boreas, doi:10.1111/bor.12317, 2018.

25

Whiticar, M. J. and Werner, F.: Pockmarks: submarine vents of natural gas or freshwater seeps, Geo-Mar. Lett., 1, 193-199, doi: 10.1007/BF02462433, 1981.

Wong, P. P., Losada, I. J., Gattuso, J.-P., Hinkel, J., Khattabi, A., McInnes, K. L., Saito, Y., and Sallenger, A.: Coastal 30 systems and low-lying areas, in: Climate Change 2014: Impacts, Adaptation, and Vulnerability, Part A: Global and Sectoral Aspects, Contribution of Working Group II to the Fifth Assessment Report of the Intergovernmental Panel on Climate Change, Field, C. B., Barros, V. R., Dokken, D. J., Mach, K. J., Mastrandrea, M. D., Bilir, T. E., Chatterjee, M., Ebi, K. L., Estrada, Y. O., Genova, R. C., Girma, B., Kissel, E. S., Levy, A. N., MacCracken, S., Mastrandrea, P. R., and White, L.L. (eds.), Cambridge University Press, Cambridge, UK, 361-409, 2014. 
Hydrol. Earth Syst. Sci. Discuss., https://doi.org/10.5194/hess-2018-507

Manuscript under review for journal Hydrol. Earth Syst. Sci.

Discussion started: 30 October 2018

(c) Author(s) 2018. CC BY 4.0 License.

\section{Hydrology and \\ Earth System \\ Sciences \\ Discussions}

(c) $\underset{\mathrm{By}}{\mathrm{B}}$

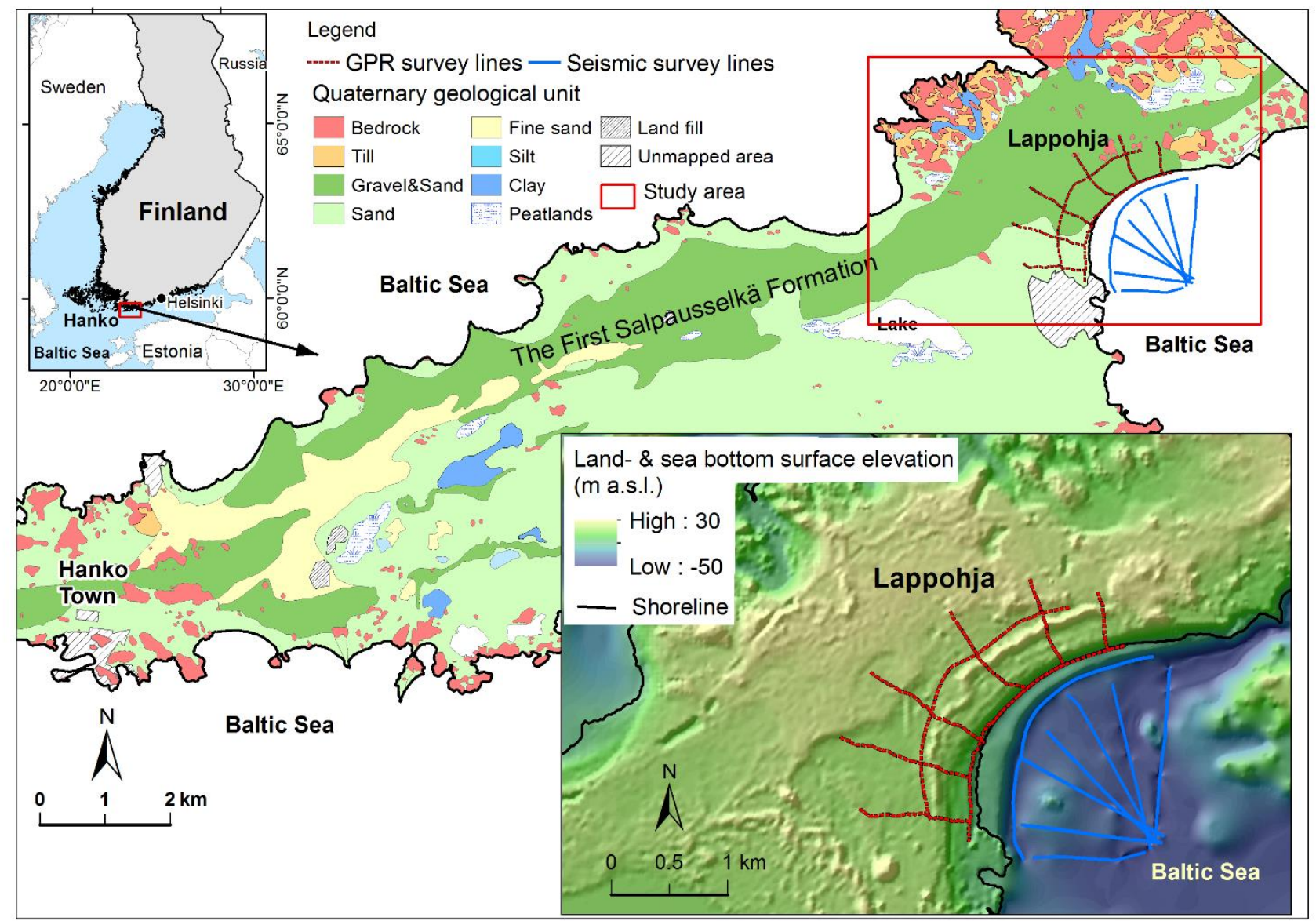

Figure 1: Quaternary geological map of the study area and location of survey lines in south Finland, northern Baltic Sea. Red lines indicate the GPR survey lines. Blue lines indicate the offshore seismic survey lines. 
Hydrol. Earth Syst. Sci. Discuss., https://doi.org/10.5194/hess-2018-507

Manuscript under review for journal Hydrol. Earth Syst. Sci.

Discussion started: 30 October 2018

(c) Author(s) 2018. CC BY 4.0 License.

\section{Hydrology and \\ Earth System \\ Sciences \\ Discussions}

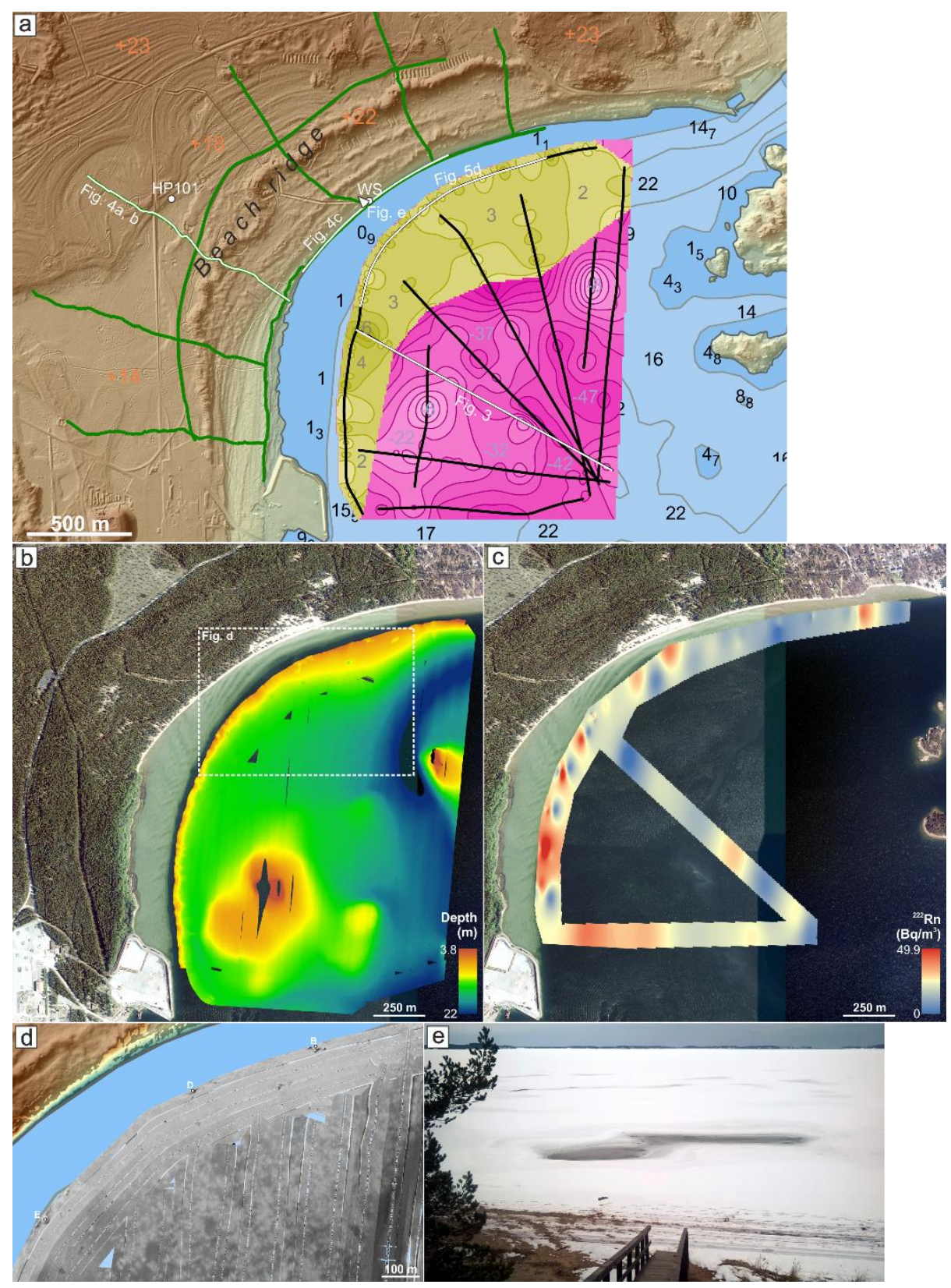

Figure 2: Maps of the study area. (a) Interpreted depth of till top surface (pink, SU2) and the interpreted thickness of ice-contact subaqueous fan foreset (yellow, SU3). The interpretations are based on offshore reflection seismic profiles as described in the text. Black lines indicate the offshore seismic survey lines. Green lines indicate the GPR survey lines. White lines indicate the survey

5 lines in Figs. 3, 4 and 5d. HP101 indicates the groundwater observation well. WS indicates the obsolete water station. (b) Multibeam bathymetric image over the offshore survey area. (c) Measured ${ }^{222} \mathrm{Rn}$ activity concentration in the sea surface water (0.5 m water depth). (d) Close-up multibeam backscatter image of the seafloor with the pockmarks E, D and B indicated. (e) Picture taken 4 May on the beach ridge toward the sea. The exact location is indicated by a white triangle in Fig. a. Note the dark patches in the winter ice that are presumably caused by SGD. Coordinate system ETRS-TM35FIN. Nautical chart: S-57 Finnish

10 Transport Agency 2017. Topographic map: National Land Survey of Finland digital elevation model 2 m 2017. Aerial photograph: National Land Survey of Finland Topographic Database 04/2017 
Hydrol. Earth Syst. Sci. Discuss., https://doi.org/10.5194/hess-2018-507

Manuscript under review for journal Hydrol. Earth Syst. Sci.

Discussion started: 30 October 2018

(c) Author(s) 2018. CC BY 4.0 License.

(c) (1)
Hydrology and

Earth System

Sciences

Discussions

\section{a: 3.5 - $8 \mathrm{kHz}$ CHIRP}

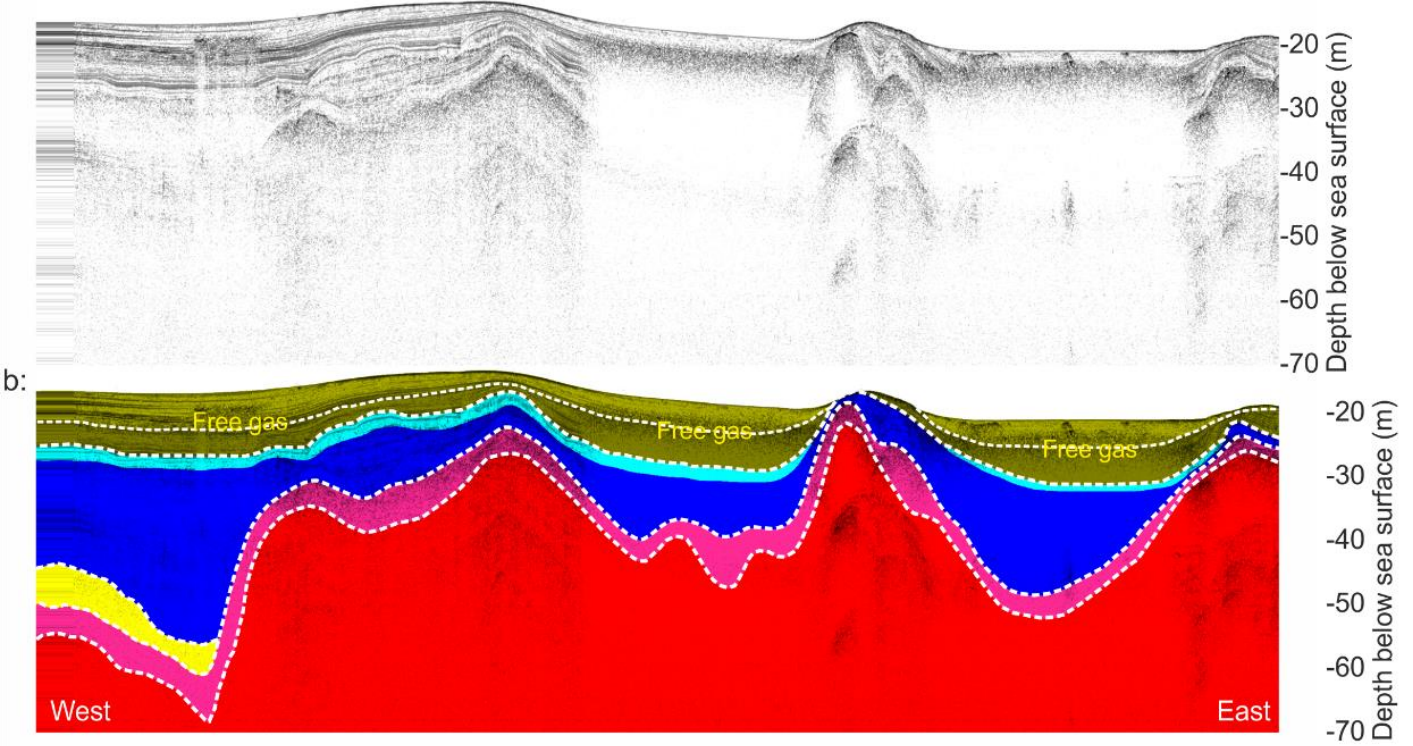

c: $250-1300 \mathrm{~Hz}$ reflectin seismic
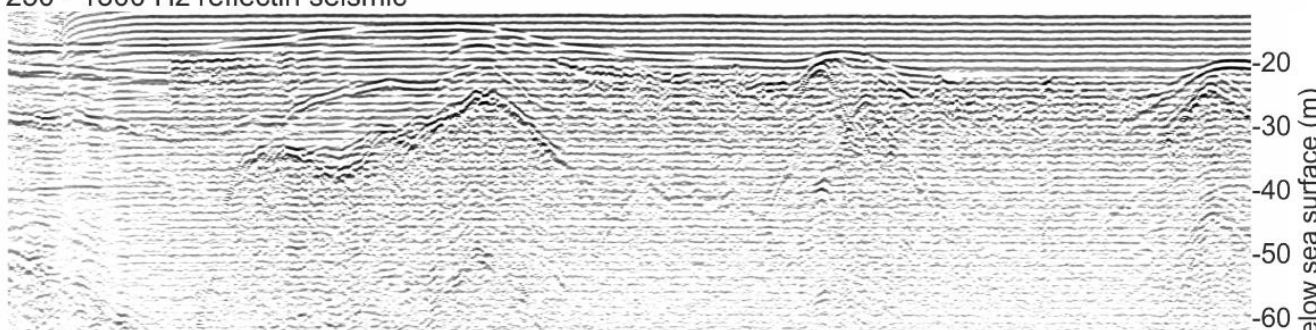

$-60 \frac{3}{\frac{3}{0}}$

-70 亭

$\mathrm{d}:$

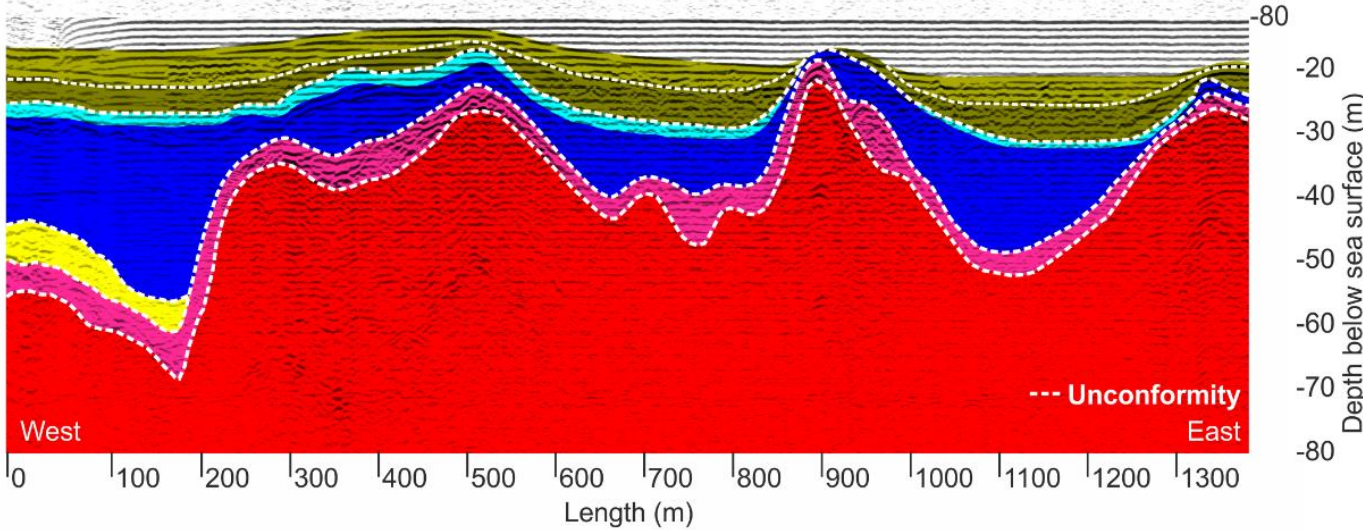

$\square$ SU5: Postglacial lake clay

SU6: Brackish-water mud drift (lower)

$\square$ SU7: Brackish-water mud drift (upper)

口U1: Bedrock

$\square$ SU2: Till

$\square$ SU3: Ice-contact fan foreset

SU4: Glaciolacustrine rhythmite

Figure 3: Offshore sub-bottom profiles collected along the survey line indicated in Fig. 1a. (a) 3.5-8 kHz CHIRP sub-bottom profile, and (b) interpretation of the profile. (c) 250-1300 $\mathrm{Hz}$ reflection seismic sub-bottom profile, and (d) interpretation of the profile. See text for details about the interpretation of seismic units. 
Hydrol. Earth Syst. Sci. Discuss., https://doi.org/10.5194/hess-2018-507

Manuscript under review for journal Hydrol. Earth Syst. Sci.

Discussion started: 30 October 2018

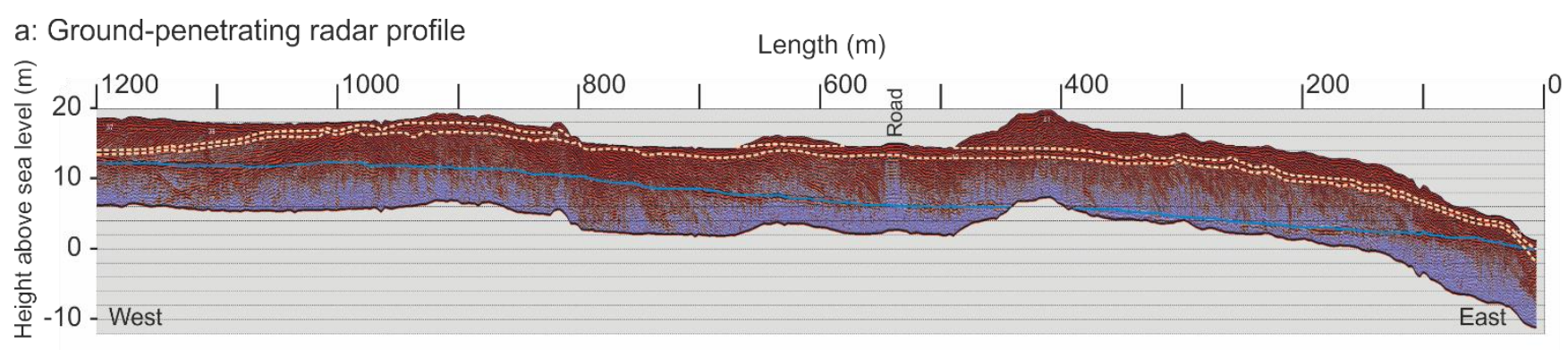

b: Ground-penetrating radar profile - interpretation

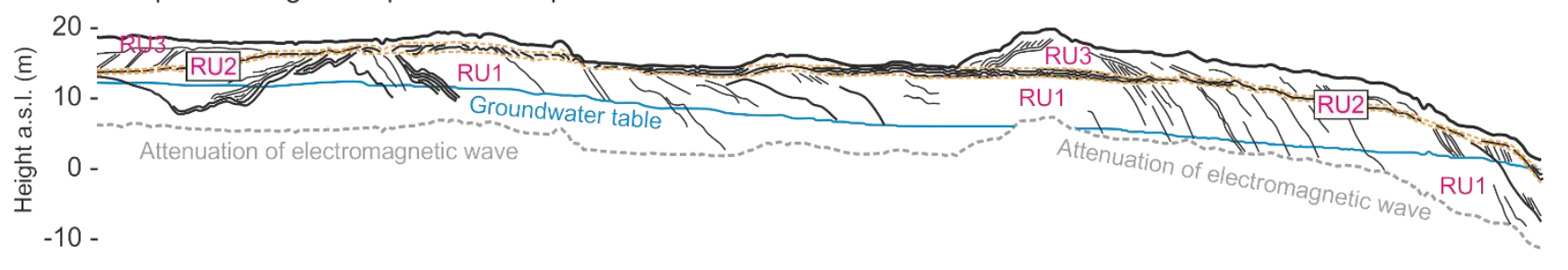

RU1: Distal ice-contact fan RU2: Shoreface lag deposit $\quad$ RU3: Beach ridges $\quad=--$ Unoonformity

c: Refraction seismic surface interpretation

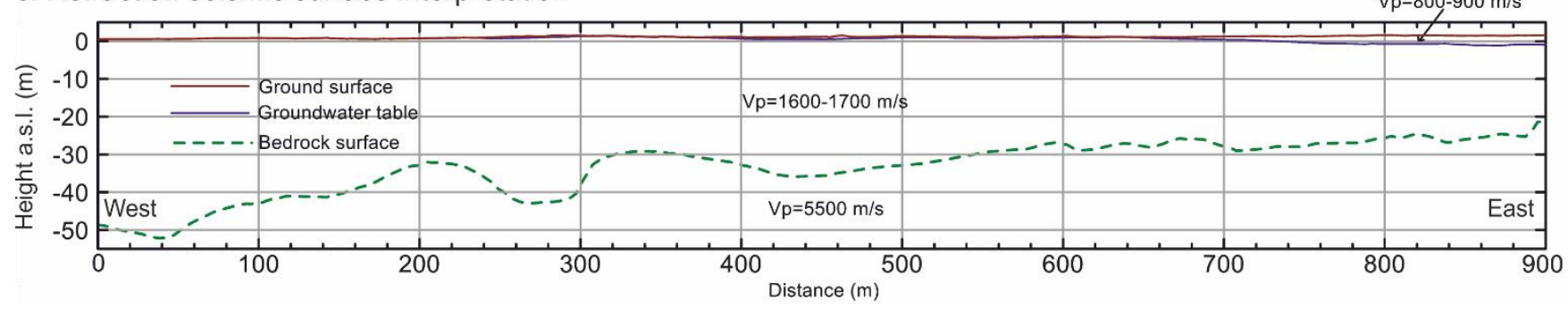

Figure 4: Onshore sub-bottom profiles. (a) Ground-penetrating radar profile indicated in Fig. 1a, and (b) interpretation of the profile. (c) Interpreted surfaces from a shore-parallel refraction seismic profile indicated in Fig. 1a. See text for details about the interpretation of seismic units. $\mathrm{Vp}$, compressional sound velocity. 
Hydrol. Earth Syst. Sci. Discuss., https://doi.org/10.5194/hess-2018-507

Manuscript under review for journal Hydrol. Earth Syst. Sci.

Discussion started: 30 October 2018

(c) Author(s) 2018. CC BY 4.0 License.

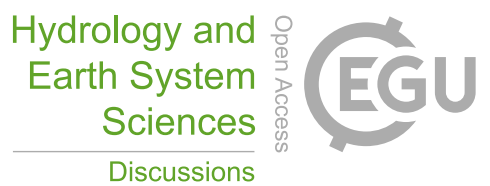

(c) (i)

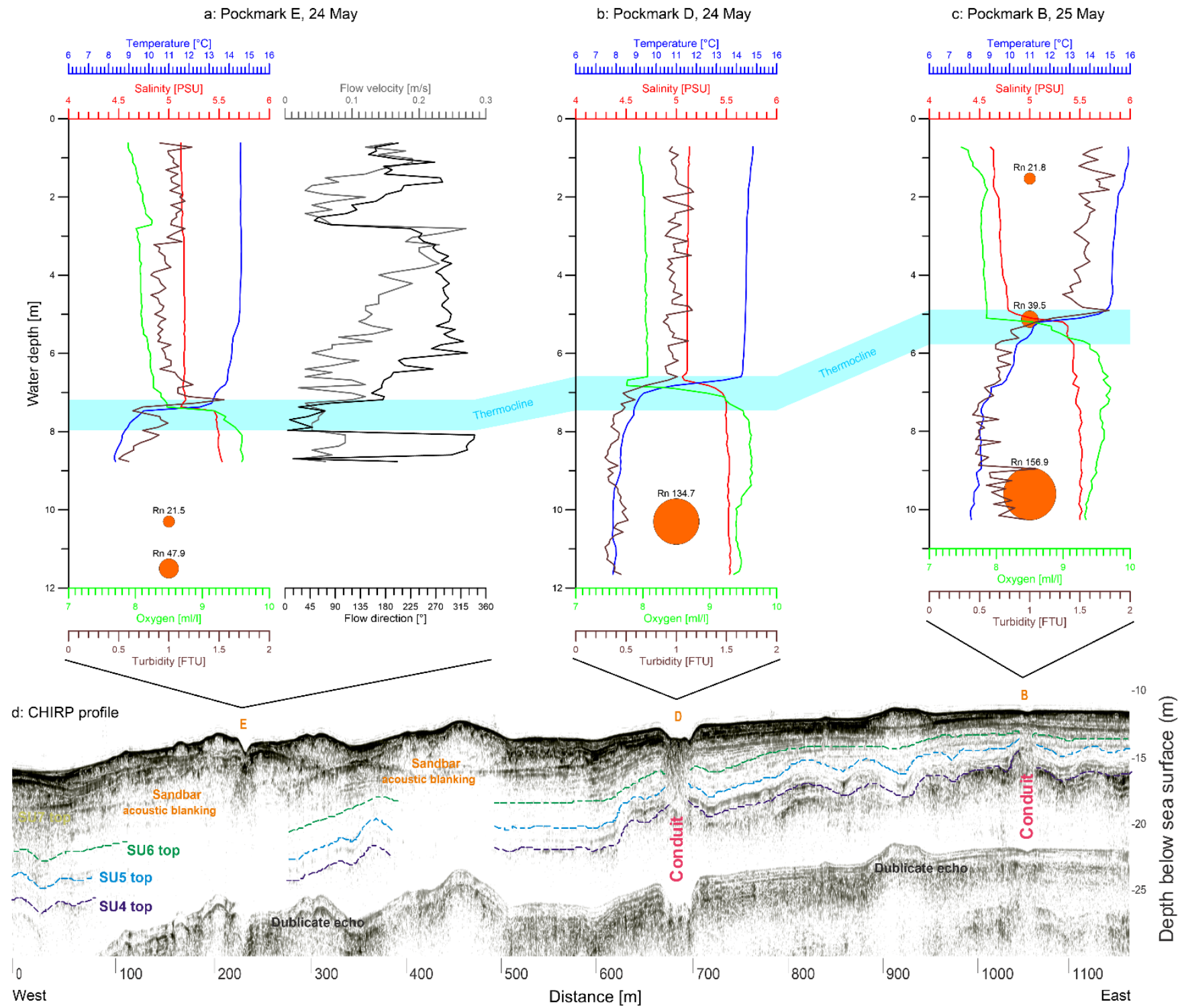

Figure 5: Water column measurements, and a CHIRP profile over the pockmarks E, D and B. (a) Water column profiles and radon point measurements at the pockmark E. (b) Water column profiles and a radon point measurement at the pockmark D. (c) Water column profiles and radon point measurements at the pockmark B. Radon activity concentrations are Bq/ $\mathrm{m}^{3}(\mathrm{see}$ also Table 5 1). (d) Interpreted $3.5-8 \mathrm{kHz}$ CHIRP sub-bottom profile indicated in Fig. $1 \mathrm{a}$. 
Hydrol. Earth Syst. Sci. Discuss., https://doi.org/10.5194/hess-2018-507

Manuscript under review for journal Hydrol. Earth Syst. Sci.

Discussion started: 30 October 2018

(c) Author(s) 2018. CC BY 4.0 License.

\section{(c) (i)}
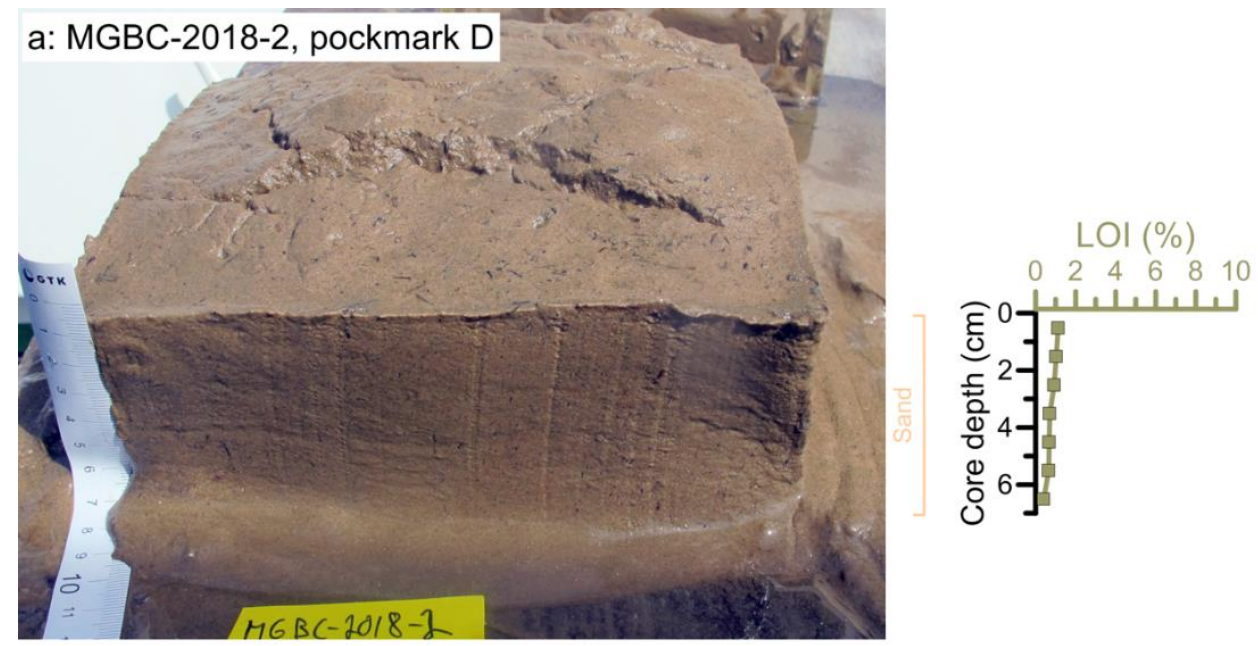

\section{b: MGBC-2018-3, pockmark E}
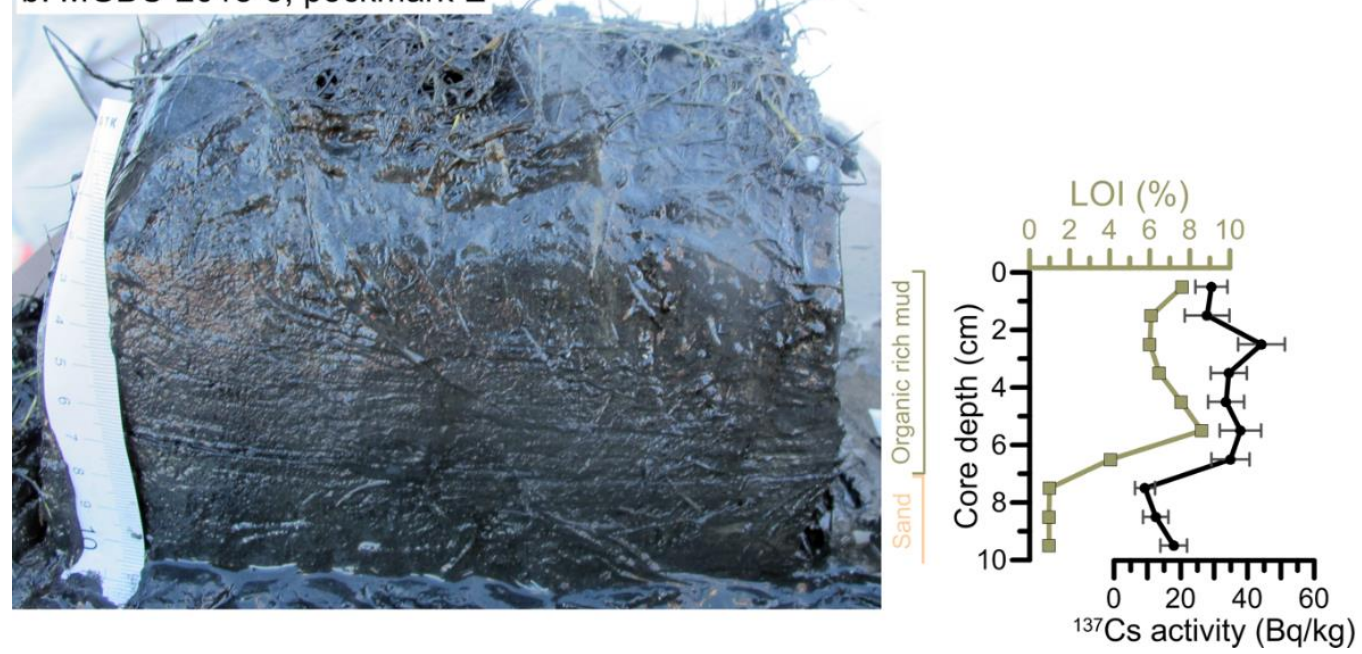

Figure 6: Images of sediment box cores with the measured weight loss on ignition (LOI) and ${ }^{137} \mathrm{Cs}$ activity content. (a) Core MGBC-2018-2 from the pockmark D. (b) Core MGBC-2018-3 from the pockmark E. 
Hydrol. Earth Syst. Sci. Discuss., https://doi.org/10.5194/hess-2018-507

Manuscript under review for journal Hydrol. Earth Syst. Sci.

Discussion started: 30 October 2018

(c) Author(s) 2018. CC BY 4.0 License.

\section{Hydrology and Earth System Sciences \\ Discussions}

(c) (i)

a: Allostratigraphic onshore-offshore correlation

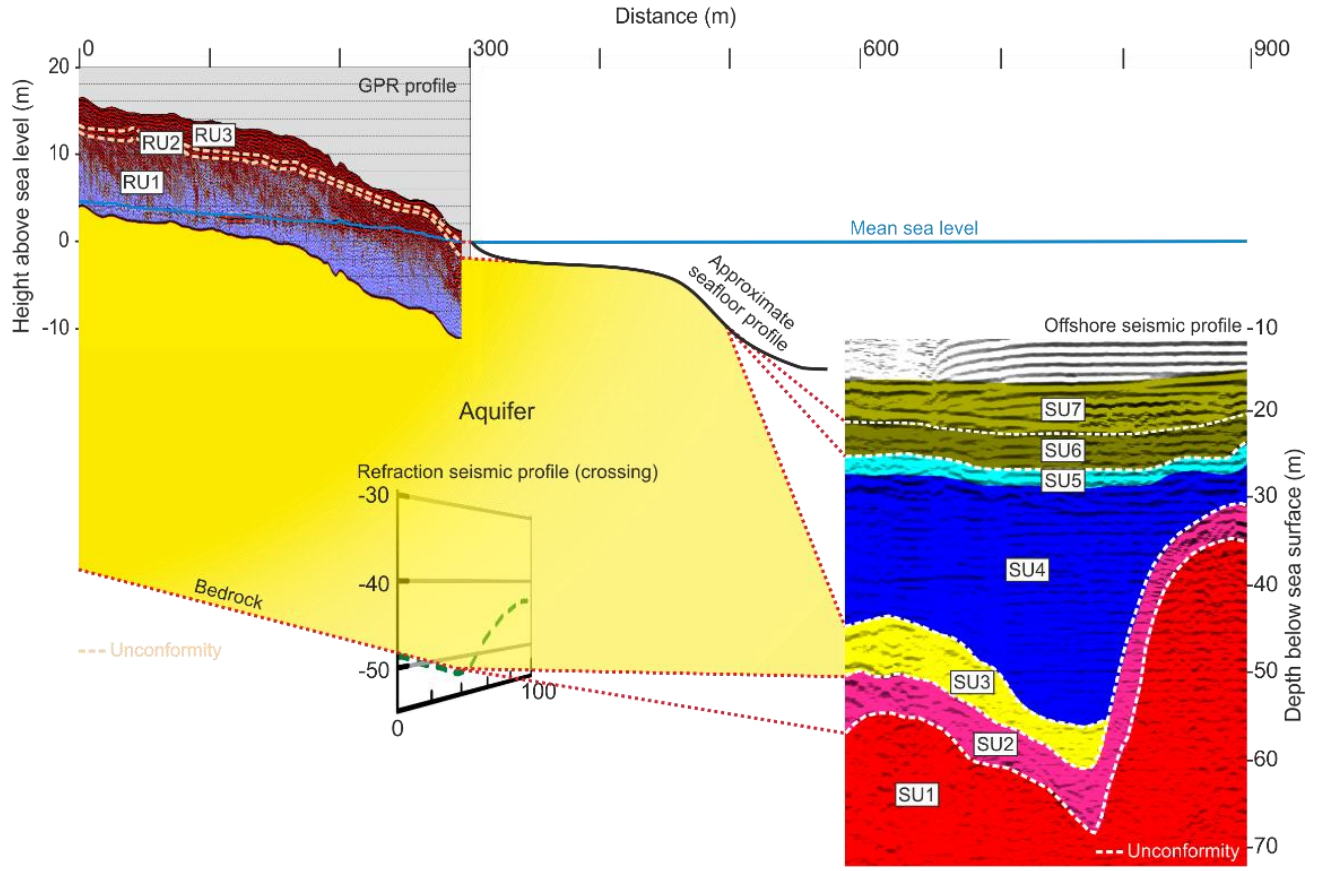

b: Stratigraphic architecture of the submarine groundwater discharge site

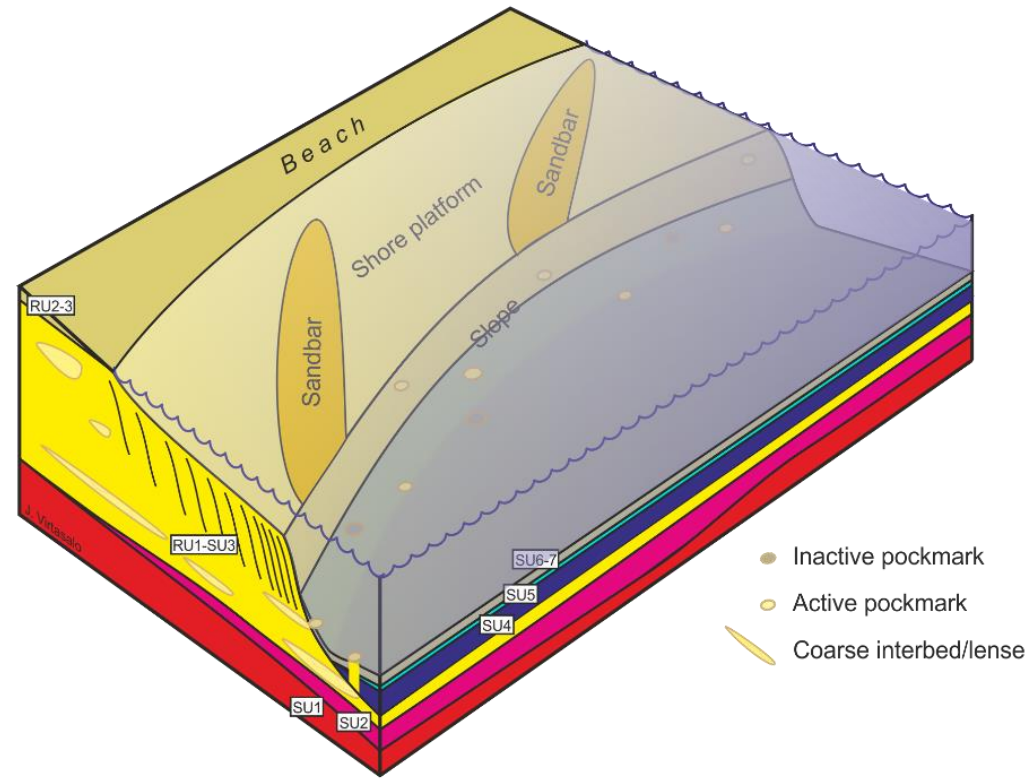

RU1: Distal ice-contact fan

RU2: Shoreface lag deposit

RU3: Beach ridges

$\square$ SU5: Postglacial lake clay

SU6: Brackish-water mud drift (lower)

SU1: Bedrock

$\square$ SU2: Till

$\square$ SU3: Ice-contact fan foreset

SU4: Glaciolacustrine rhythmite

Figure 7: Summary diagrams. (a) Allostratigraphical correlation of unconformities between the onshore ground-penetrating radar and refraction seismic profiles, and the offshore seismic profiles. (b) Stratigraphical architecture of the studied submarine groundwater discharge site. Not to scale. 
Hydrol. Earth Syst. Sci. Discuss., https://doi.org/10.5194/hess-2018-507

Manuscript under review for journal Hydrol. Earth Syst. Sci.

Discussion started: 30 October 2018

(C) Author(s) 2018. CC BY 4.0 License. (c) (1)

Table 1 . Measured ${ }^{222} \mathrm{Rn}$ activity concentrations in sea and groundwater.

\begin{tabular}{|c|c|c|c|c|}
\hline Target & $\begin{array}{l}{ }^{222} \mathbf{R n} \text { in } \mathbf{B q} / \mathbf{m}^{\mathbf{3}} \\
\text { (1-sigma uncertainty } \\
\text { in brackets) }\end{array}$ & Date & $\begin{array}{l}\text { Latitude N } \\
\text { (ETRS89- } \\
\text { TM35FIN) }\end{array}$ & $\begin{array}{l}\text { Longitude } \\
\text { E } \\
\text { (ETRS89- } \\
\text { TM35FIN) }\end{array}$ \\
\hline $\begin{array}{l}\text { Shore parallel survey at sea, } 0.5 \mathrm{~m} \text { below } \\
\text { sea surface }\end{array}$ & $\begin{array}{l}\text { mean } 16.9 \quad(12.3) \text {, } \\
\text { median } 14.4, \mathrm{n}=56\end{array}$ & 23 May 2018 & & \\
\hline Groundwater, observation well HP101 & $12129(1258)$ & 24 May 2018 & $59^{\circ} 53.616$ & $23^{\circ} 12.674$ \\
\hline Groundwater, obsolete water station & $37433(2216)$ & 24 May 2018 & $59^{\circ} 53.660$ & $23^{\circ} 13.688$ \\
\hline Pockmark E, $0.5 \mathrm{~m}$ above sea floor & $47.9(14.6)$ & 24 May 2018 & $59^{\circ} 53.501$ & $23^{\circ} 13.736$ \\
\hline Pockmark D, $1 \mathrm{~m}$ above sea floor & $134.7(26.4)$ & 24 May 2018 & $59^{\circ} 53.700$ & $23^{\circ} 14.146$ \\
\hline Pockmark B, $1 \mathrm{~m}$ above sea floor & $156.9(33.9)$ & 25 May 2018 & $59^{\circ} 53.771$ & $23^{\circ} 14.478$ \\
\hline $\begin{array}{l}\text { Pockmark B, } 5 \mathrm{~m} \text { below sea surface } \\
\text { (thermocline) }\end{array}$ & $39.5(7.9)$ & 25 May 2018 & $59^{\circ} 53.771$ & $23^{\circ} 14.478$ \\
\hline Pockmark B, $1 \mathrm{~m}$ below sea surface & $21.8(12.2)$ & 25 May 2018 & $59^{\circ} 53.771$ & $23^{\circ} 14.478$ \\
\hline $\begin{array}{l}\text { Pockmark E, } 1.5 \mathrm{~m} \text { above sea floor, } \\
\text { revisit }\end{array}$ & $21.5(6.1)$ & 25 May 2018 & $59^{\circ} 53.498$ & $23^{\circ} 13.732$ \\
\hline
\end{tabular}

